\title{
An Inquiry Based Learning Program for Developing Reflective Writing Skills and Reducing Writing Apprehension among EFL Post Graduates
}

By

\author{
Mona Salah Abd-Allah Othman*
}

\begin{abstract}
The purpose of this research is to investigate the effectiveness of a proposed program based on inquiry learning for improving EFL reflective writing skills and reducing writing apprehension among EFL post graduate students at the Faculty of Specific Education. The design of the research is a quasi-experimental. Two groups participated in the study: an experimental group and a control group. Both groups were tested before and after the intervention. The participants in the two groups were 30 post-graduate students who were chosen randomly from the first year special diploma students enrolled in the curriculum and EFL instruction department at the Faculty of Specific Education, Zagazig University, Egypt. They were divided into two groups: an experimental group $(\mathrm{N}=15)$ students who were adopting the proposed program based on inquiry learning and a control group $(\mathrm{N}=15)$ students who were taught in the regular way. The instruments of the research included an EFL reflective writing skills test and the Daly-Miller Writing Apprehension Test. Results of the research revealed a statistically significant difference between the mean score of the experimental group and that of the control group in the post-test of EFL reflective writing skills in favor of the experimental group. In addition, students' writing apprehension was decreased. Accordingly, it was concluded that the inquiry-based learning program was effective.
\end{abstract}

KeyWords : Inquiry based learning, EFL reflective writing, writing apprehension, postgraduates, Specific Education, Egypt.

\section{Introduction:}

Inquiry- based learning (henceforth IBL) is a teaching approach that encourage students to discuss academic content by posing, investigating and answering questions. It is a part of inductive teaching - learning approaches. These approaches start with several observations or data to interpret or a complex real-world problem and as the students study the data or problem they generate a need for facts, procedures and guiding principles (Prince and Felder .2006)

The inquiry based learning approach has its origins from constructivism and is in line with studies on motivation, intellectual growth and learning methods. Therefore according to the constructivist theory of learning, successful learning interaction is that makes use of what students already know for enabling them to be active learners; provide true learning 
opportunities; and involve students working together in small groups (i.e. in collaborative or cooperative learning). The basic approach to inquiry learning is then based on the philosophy of constructivist learning.

Constructivist learning strategies capitalize on learning via critical and creative thinking through inquiry and problem solving. According to (Asselin, et. al, 2003) student inquiries are motivated to discuss new theories and understandings through personal observations and explorations, as well as experiences,

In addition, inquiry-based learning encourages students to how after learn autonomously to enhance their own thoughts (Suhartono, et.al, 2014). It is a way of learning and teaching through interrogation and experimentation (Ajit, et.al, 2016). IBL may also make learners more critical, analytical and creative, which enable them to work at any condition than any other learning method. Inquiry learning demands a classroom climate where the students feel free to work, have a notion, make inference and make educated assumptions across the learning process in the classroom (Suhartono, et.al. 2014). This method dominates the complex work of learning. Obviously, it prioritizes the knowledge and experience students bring to the classroom and it promotes active problem solving, communication of results, and the shared construction of new ideas.

According to (Aditomo, et al., 2013) inquiry based learning is an innovative method for developing all language skills. One of them is reflective writing. Reflective writing varies from most other forms of academic writing because it leads the learner to examine his own responses to a given topic or situation. Importantly, the learner needs to go beyond simply describing course content. Good reflective writing should critically engage with and form links between the learner's own and others' ideas.(Helyer, 2015 )defines "Reflective Writing" as an analytical practice in which the writer describes a scene, event, interactions, thinking, memories, the way they pass, the person's thoughts or situations in a particular incident, event, feeling or situation.

The implementation of Inquiry-Based Learning, however, has placed little emphasis on teaching reflective writing and decreasing writing apprehension in EFL classroom. Therefore, the aim of this study is to explore the role of Inquiry Based Learning in improving reflective writing and reducing the level of writing apprehension. In particular, the current study seeks whether Inquiry Based Learning can significantly improve reflective writing and reduce the level of writing apprehension, find out the students' perception toward the implementation of Inquiry Based Learning to improve reflective writing and decrease writing apprehension.

Due to these purposes, it is hoped that the Inquiry Based Learning leads the students to think critically. Adopting IBL the students are expected to think effectively in order to find their own answers from the questions they are facing. Similarly, IBL lets the students connect with their learning by stimulating materials provided through questions about topic. The learning process organized and managed well enables teacher to prepare qualified materials related to IBL process. Sometimes, teachers lose their idea about classroom interaction to keep the students active and fully interactive in the learning process. Then, the IBL may 
become the solution in which the students get active to control their learning process. Learning by doing introduced by Dewey (1937) (as cited in Alberta learning, 2004) reinforces the importance of allowing students to explore subjects which corresponds with their own questions as an essential stage of inquiry. Thus, from these formulated questions, inquiry will be a tool that connects the curriculum and their interest, abilities and habits.as the basic theory behind this approach provides the students with full interactive and students ${ }^{\text {ee }}$ experiencebased learning process.

In the recent time, students face many difficulties in writing English language and this eventually affected their ideas, communication their level of writing apprehension in English language. Generally, these problems can be classified into linguistic, psychological, cognitive and pedagogical categories (Haider, 2012; Hyland, 2003). They contest with the structural components of English; because an unsuitable thematic tangles the content and the understanding of the text, which a reader deciphers through involvement of a mental process (Quintero, 2008; Nik, Hamzah, \& Rafidee, 2010). An incoherent text also fails to communicate ideas which causes lack of confidence in learners even if they have mastered syntactic, lexical and grammatical instruction over text composition (Rico, 2014). Students' lack of confidence is also caused by a teaching strategy which does not adapt to students' learning styles and cultural backgrounds (Ahmad et al., 2013). Ability of students, particularly who are not native speakers find it so difficult to correctly and boldly express themselves in English.

Having a good English writing skills and a low degree of writing apprehension require regular practice, fostering students' interest and, motivation, students' freedom in choosing the topics and interrelationship with other people. This could be used for enabling the students to know and practically exercise the writing process. Further, the teachers can adapt their pedagogic approaches and can design such activities and tasks that could motivate and encourage students by giving them freedom of selecting topics of their interest (Pineteh, 2013; Quintero, 2008). It will change their writing types, perhaps, via more practice and by including practical and cognitive skills which give the writer control over the expression of linguistic and domain-specific knowledge (Kellogg \& Raulerson, 2007). In addition, it will be appropriate for language and content teachers to monitor their students from broad perspectives (Nik, Sani, Kamaruzaman, Hasbollah, et al., 2010).

It has been posited that for students to perform well in education, there is a good chance if the student has the good background or ability to express the conceived ideas and mindset in English language. However, learning in the classroom has possessed the required potentials to assist students perform well in the English communication and writing. It is observed that students mostly from the countries where the English language is not the native or first language often perform worse in their final examination at the high school education level. The purpose of this study is to emphasize that the English writing predicaments as a result of time commitment to study English. Thus, both the classroom and the outside classroom training have the contributing effects on the English reflective writing and the level of writing apprehension. These several devices have been 
employed in the process such as developing the teachers training skill and introduction of student center learning. This idea emanated as result of appreciating that the student preferred having the freedom to exploit their teaching rather than the strict traditional way of classroom training, where student learning and activities were under the full control of teachers. When students are allowed to apply their free thinking in their learning they develop better educational performance. It encouraged students' reflective writing and reducing their writing apprehension. Further, the teachers motivating learning strategies have received attention as a means of having an encouraging impact on the student learning

However, for effective application and understanding of inquiry learning, various types of inquiry levels need to be understood. (Ahmad, J. et.al, 2014). have applied different terminology to represent inquiry learning ranges from guided inquiry, structured inquiry, scientific inquiry, open inquiry, full inquiry, and authentic inquiry. Thus, the lack of distinctive level within the inquiry learning poses challenges on the understanding and application of inquiry learning in order to achieve its effectiveness. For improving the English writing skill among the high school students, the understanding of levels of inquiry among the designated students is utmost important. The national science education standards argued that the nomenclature and terminology usages differences in inquiry earning is to categorize the inquiry in their level basis. This will help in categorizing the effectiveness of inquiry on student writing skill and assist in establishing the effective level of inquiry that is being acknowledged among the tested students.

\section{.Inquiry Based Learning (IBL)}

\subsection{Definition of Inquiry based learning}

"Inquiry" is an investigation or a search "for truth, facts, data, or knowledge...seeking data by questioning and searching (Exline, 2004: 31).

( Petr,2010, p. 139) mentions that the 'inquiry- based instruction' is a form of instruction in which the information produced through the resolution of a particular problem in consecutive steps involves setting the hypothesis, choosing the appropriate instruments to indicate a certain phenomenon, obtaining the results and their processing, concluding, discussing and quite often cooperating with fellow students .

(Papáček, 2010, p. 40) states that the inquiry-based instruction is one of the efficacious stimulating techniques of the problem-posing education and it is dependent upon the constructivist theory. The teacher does not transfer the subject matter in a form of a wholeclass presentation in an already-done way but s/he creates the knowledge by the use of the problem solving and a system of asked questions (communication apparatus). Moreover, (Papáček, 2010) illustrates that the basic feature of the inquiry-based learning involves the following stages: the learners ask the inquiry related questions; they search on the evidence, based on the evidence, they form clarification, they evaluate the clarification with a possibility of using alternatives in the clarification, and they communicate and check their clarification. 
The internet site of School of inquiry-based instruction (2014) states that during the processing of the inquiry-based learning the teacher does not turn the subject matter in a form of a whole-class presentation in an already-done way but $\mathrm{s}$ / he forms the knowledge by the use of the problem solving and questioning (communication instruments). The teacher has a function of the insightful guide during the problem solving process and s/ he leads the learner in the way that is common for the real research.

Ajit, et.al. (2016) defines Inquiry-Based Learning as a way to learn via questioning and experimentation. An ELT context, learners could remark that IBL is an effective way of learning English language. IBL offers more opportunities to develop interesting, crosscultural and practical learning.

From the aforementioned definitions, it could be concluded that inquiry-based learning is an approach, which stimulates the students' prior knowledge and experiences before coming up with the entire materials provided by instructor. It contains questioning, drawing inferences and finding out the solutions of the problems then evaluates the process of the inquiry experienced before. It includes questioning, planning, investigating, recording, reporting and reflection.

\subsection{The Benefits and Advantages of Inquiry based learning}

Through the utilizing inquiry based learning approach, the students can be more creative, active, positive and more independent. It gives students the chance to improve their lifetime skills, learn to cope with problems that may not have clear solutions, deal with changes and challenges to understanding and shape their search for solutions now and in the future. Further benefits of inquiry based learning can be summarized below according to (Stevens, 2006).

\section{A. improving material retention}

While inquiry-based learning is often viewed as a risky deviation from the curriculum, it shouldn't be. In contrast, if the teacher knows what he is doing, he will keep students close to the program, enabling them to ask questions about the topics they should be learning. As for retention, research-based learning is based on curiosity and hippocampus - curiosity is activated by the brain region which shapes memory. In other words, it is precisely because students feel interested in what they study that they remember the material more likely.

\section{B. Promoting initiative}

The conventional approach to education underlines the passivity of students - they do not actively invest in themselves and wait until they receive the right knowledge. How well they are able to repeat what they heard in learning the material is evaluated. Contrary to this approach, inquiry-based learning forces one to find an individual response, to facilitate selfdirection and initiative. The student is more likely to decide on each part of the work he does 
whether or not to employ a test writing service to receive assistance with a particularly unpleasant task.

\section{C. improving understanding of the subject}

When students themselves answer a question, they become more and more conscious of what they have learned through their own study. In certain cases, they are more interested and more full and proud than getting just answers from their teachers. It removes the ability for students to actually take the outcomes of the instructor for granted - they will never obey the process that they clearly do not understand and they will not do so if they do not understand any aspect of the process until they do.

\section{D. making learning more rewarding}

Inquiry-based learning connects learning with success. Getting a reply on your own is much more enjoyable and worthwhile than getting somebody else's ready-made solution. Last, research-based learning helps create a certain attitude that receives recognition and recognition not from teachers and parents in the act of learning and accomplishment itself.

\section{E. utilizing each student's unique learning style}

Traditional instruction is one-size-fits-all or at least one. There are no considerations of the variations between students. Instead, survey-based learning encourages students to learn on their own terms using their own strengths. You can work for yourself or in groups, chat or investigate with content with optimum ease.

The IBL suggests the subjects and questions that students want to explore in order to answer the problems they are interested in. This helps the learner to grasp and use the formulation of questions. Teachers should instruct good questions from a material point of view but also grammatically in the appropriate structures.

Furthermore, for a number of years researchers suggest studies and issues, as they allow students to think about metacognitive strategies. (Brown, 2000) notes that students who can use these techniques are better language learners. IBL shifts the nature of conventional courses, since students don't passively take notes like other approaches, but instead play an active role in selecting the topics that they study and in producing the outcomes of their own studies. This allows students to take their lessons more attention and use the target language, since they have a sense of control at a more acceptable language level. During the cycle, students must speak to other members of their community about their findings, which promote greater contact in both written and oral ways. Students need to prepare reports on new discoveries and successes and formulate new problems in order to deepen the study process. This facilitates the use of both written and oral forms of the target language in a meaningful way.

As a collaborative learning facility for the role of technology in IBL, (Stevens, 2006) supports his application, as its positive impact on motivation and building up knowledge. Students do 
not just use it to understand content but also the world around them in greater depth by interacting synchronously or asynchronously with other students, teachers and subject matter experts.

According to (Roestiyah, 2001: 76-77), Inquiry Based Learning is characterized by the some advantages as follows:

(1) Creating and improving student self-concept;

(2) Assisting student to remember and pass knowledge;

(3) Leading students to learn and work on their own and to live independently, frankly and open-mindedly;

(4) Encouraging learners to consider intuitively and to assess theories;

(5) Providing intrinsic satisfaction;

(6) Stimulating the learners in teaching and learning procedures;

(7) Enhancing the talent of the students;

(8)Granting students the right to study alone;

(9) Avoiding the traditional way of studying;

(10) Giving the students sufficient time to assimilate and accommodate the information.

\subsection{The steps of inquiry based learning}

(Petr, 2010) argues that there are four key inquiry based learning steps;

1. Student development questions;

Writing tie in requires them to develop a problematic statement requiring them to answer their questions by means of a constructed answer.

\section{Researching the topics using time inside class;}

Some of these matters are necessary for students to access the head researcher in the room. The instructor does or does not do the job, however, you can accurately lead them and model research methods.

3. Having students to present what they learned;

When the teacher presents his students what they have learnt, should the student create and present a climax artefact that the teacher uses and can teach as the culmination of for which many people can understand content, but communicate.

4. Asking students to reflect on things worked about the process and things didn't Reflection is a key issue and it is not simply a question of asking them to reflect on the topic. It's a process itself that reflects. This is where metacognition is involved. Think and think about how you learn not only what you have learned. 


\subsection{The process of inquiry based learning:}

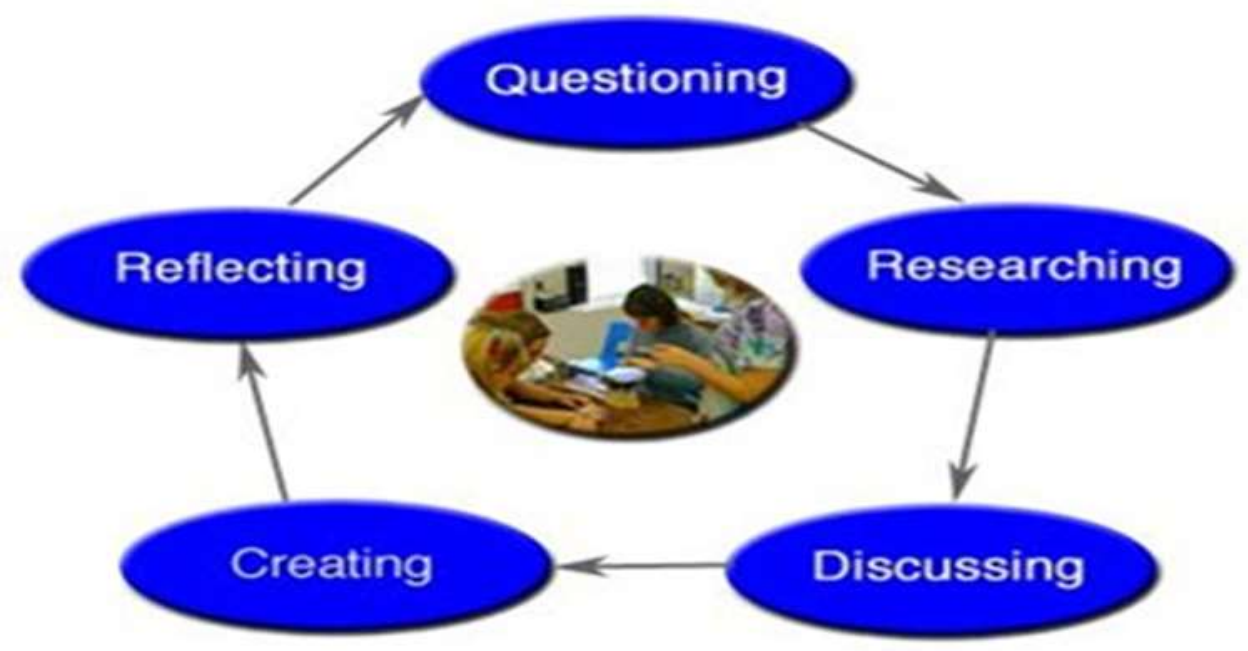

Title of the Figure: The Inquiry based Learning Process.

Source: $\underline{\text { http://www.thirteen.org/ed on line /concept2class/inquiry/credit.html }}$

Inquiry based learning process includes planning, retrieving, processing, creating, sharing and evaluation. It contains two components, affective and cognitive associated with metacognitive (Albert Education 2005).

For students, this process often involves open-ended quest into a matter or a problem, requiring them to participate in evidence-based causes and creative problem-solving, as well as "problem discovery." this process aims to lead the educator to be more responsive to the students' learning needs, and know when and how to introduce students to ideas that will move them forward in their inquiry. Together, educators and students co-author the learning experience, accepting mutual responsibility for planning, assessment for learning and the advancement of individual as well as class-wide understanding of personally meaningful content and ideas (Fielding, 2012).

There are some principles that are included in IBL stages, e.g. engagement, research, illustration, preparation and evaluation. An inquiry based approach begins firstly with engagement of the students prior to illustrating. This do for various purposes: to create a conflict between prior learning and new scientific understanding. Such a conflict will allow students to ask questions, to attract student attention and focus and to generate and evaluate alternative conceptions that previous students have developed. The second stage is research without an explanation from teachers. During this phase students are asking questions, hypothesizing, without the teacher's direct input but guiding, collecting evidence, recording and organizing information, sharing observations, making claims for evidence, drawing conclusions and working collaboratively. Third, it's a stage of illustration. During this phase, the students draw upon experiences to provide their ideas and illustration in their own words. They use evidence to support ideas, critically appreciate explications, and listen to others in a critical and respectful manner. Preparation is the next step. During this phase, students apply scientific terms, definitions, use new contexts for understanding, use past knowledge to ask 
questions, propose solutions, take decisions and design research, draw reasoned conclusions from the evidence and make sure that they understand their peers. Finally, evaluation stage. During this phase, students demonstrate their comprehension of ideas and concepts, answer open questions, assess their progress, ask questions and participate in peer evaluations.

\subsection{Inquiry - Based Learning in Classrooms}

(Ismaile, 2006) illustrates that in inquiry based learning, the environment of the class should be filled with learning resources that develop and inspire of order to provide a fruitful inquiry-based classroom. It can also have responses to questions from students. Therefore, a lot of reading materials such as books, magazines, brochures, pamphlets, newspapers related to the subject under review are better prepared for the class. Access to CD-ROMs is also helpful for students as they can be very helpful as well as fascinating since they are immersive and contain simulations. The use of the Internet as it connects to a multitude of information can also be promoted. Digital educational learning can be promoted, such as by web-based programs that rely on the process of inquiry. Innovation Media, Inc. at Bio point for instance, the online gallery has many Web Quests, Mini Quests and Project Pages created by teachers. Within a gallery of educational events grouped by grade level, subject and activity form, classroom teachers have the ability to view over 250 different activities.

\section{Web Quests}

A successful web Quests offers learners the ability to participate in an effective exercise based on inquiry. Any of the services are sourced from the Internet through A Web Quest. The students also work cooperatively, playing multiple positions relevant to a real challenge. The students would create a software that would encourage them to present the possible solutions or responses to the problem given. Perfect Web Quests could contain, according to (Clarke, 1990):

1. Activities that can promote teamwork, such as collaborating with pairs or groups.

2. Motivational aspects such as offering students a role to play (e.g. a writer, a teacher, etc.) and a circumstance in which to act (e.g. you were asked to cover a disaster deadline as a teacher) etc.

\section{Mini Quests}

Mini Quests are online instructional modules developed by the teachers for the student inquirers that facilitate logical thinking and information creation. In general, Mini Quests are created in around 3 to 4 hours by web-savvy educators and are planned to be done in one or two-hour class sessions. It is simple and can integrate into a curriculum series easily (Clarke, 1990). Typically, the operation contains real task simulations. Students are asked, for instance, to be a writer and to produce newspaper columns for the school and have to come up with authentic article findings meeting the criteria for inquiry-based learning. 


\section{Project Pages}

A project page includes a mission, tools, product and review (rubric) portion of the scenario and broad inquiry activities (Clarke, 1990). To teach longer or more complex curricular cycles, a project page is usually used. In order to include material that can promote insightful interactive learning, developers of successful project sites can provide and integrate as many specific web tools (simulations, videos, primary source information, collections, graphics, etc.) providing content that can inspire thrilling simulated learning.

\subsection{The Main Types and Phases of inquiry based learning.}

There are four main types of inquiry based learning:

1. Structure inquiry: Students follow the teacher's instructions as the entire class.

2. Control inquiry: Teachers selects topics and demonstrates the students' resources will use to answer questions.

3. Guide inquiry: Teacher selects topic/questions and students design product or solution

4. Free inquiry: students chooses their topic without reference to any prescribed outcome.

According to (Caputo, 2014) the Inquiry Based Learning has six phases: planning, retrieving, processing, creating, sharing and evaluating. These phases are essential for reflecting on the process. Together they contains together the affective and cognitive domains related with metacognition. Moreover, reflecting to the method is important to all stages in the Inquiry Model.

\section{- Planning Phase}

According to (Jonassen, 2000) it is the first and the utmost significant stage of the whole process. At this phase of the inquiry process, inquirers practice some active procedures such as:- 1- Experiencing a sense of optimism about the tasks. 2- Understanding the main goal of inquiry-based learning projects which is Developing students' learning to learn skills. 3Meeting the need or interest about a topic. 4- Determining the main problem that needs to be resolved. 5- Choosing the needed inquiry questions. 6- Investigating their questions. 7Finding the information they need to know regarding a specific topic. 8- Presenting information to a specific audience. 9- Setting criteria for assessing their research product and process.

At this stage it is essential also for instructor to give certain courtesy to students with little or no background knowledge of a topic to help building their success and progress . This can be accomplished by; 1- Providing those students with information and background knowledge. 2- Motivating students to learn more. 3- Enhancing students' productive inquiry. 4- Involving students in topics or themes.

The researcher asserts that the goal of this phase according to her thesis is to stimulate the students to get excited about engaging in the writing topics. Firstly, the instructor asks learners about the writing topics of trying to connect it with their prior knowledge. After that, the instructor helps students to propose and answer the questions about the topics. Then, in 
pairs they discuss the topic and finally share opinions .All these steps enable effective engagement in the topics before coming to the real passage so that they could identify the whole components of the reflective essay. The result is to activate the reflective writing process by implementing the meaning of the passage to individual's background information and enhancing students' expectations, confirming or rejecting or modifying what they would write.

\section{- Retrieving Phase}

This is the second phase of the inquiry process where the inquirers think deeply about the needed information and their prior knowledge (Johnson \& Adams, 2011). This process of thinking and searching about information needs a considerable time before students' being able to decide for their inquiry. This is a challenging process for the endurance of students in searching information as at the beginning of this process students are enjoyable, active and attractive but they become bored and frustrated when they cannot find the information particular to their inquiry or cannot handle the unrelated information as the amount of resources increases,

(Alberta, 2004).To overcome this feeling of frustration, instructors have to practice some activities: 1. Training students to use suitable skills and strategies to select relevant information. 2. Helping students to adjust and modify inquiries and training them that these feelings are ones that all inquirers experience. 3. Helping students to understand that the information they find is not objective facts. 4. Encouraging higher thinking such as comparing, contrasting and synthesizing data.

The researcher concludes that this phase is related to reflective writing directly and writing apprehension where the learners are provided with some strategies to write a reflective essay without anxiety. The value of this phase is in helping learners to be active writers and to encourage them to find out the strategies asked for.

\section{- Processing Phase}

This is the third phase of the inquiry process which is emphasized by finding the attentionll for the inquiry. The subject area that the inquirer chooses to explore is determined by the focus on the aspect of inquiry process. Based on (Johnson \& Adams, 2011) determining the focus is not an easy process. It is not limited to narrowing the topic; it also involves compelling thesis statement and a personal perspective. Focusing and narrowing the main topic is essential for inquirers as it gives them a sense of relief and elation. This phase is also concerned with determining which information from the available resources is suitable for the focus of the topic. Selecting information needs a certain concentration to be able to select from the too little information or the excessively information. The researcher concludes that this phase explains the result of the used writing strategies. Providing deeper understanding about the text is considered a critical part at this phase which is reflected through explaining what students got from the exploration phase. Students use their own words to reflect on the ideas of the text using experience and evidence from the text to support their ideas. 


\section{- Creating Phase}

This is the fourth step where students organize their information. Creating a presentation format can be achieved by using one's own words to deliver the information (Friesen, 2010). Student's ability to contain all their new learning in their product and their competence to result in too much information will help encourage them and raise their confidence. Instructors play an active role in this phase to build student success through teaching students the skills and strategies that allow them to restrict or focus on their information. Instructors also teach learners the positive audience skills which can support students through this phase. According to the researcher, this phase is necessary to improve reading skills. This improvement can be accomplished through familiarizing the students with the text, helping them apply their understandings to new concepts, comprising several questions and answering questions. Through answering questions randomly the instructor can enhance his students' use of the appropriate terms to connect their understandings from the explanations and remind students of alternatives.

\section{- Sharing Phase}

This is the last phase of the inquiry process .At this state students become satisfied with their product, new skills and understandings and willing to share it as a result of getting enough supports throughout the inquiry process. Students feel that they have done well on their assignment and this leads them to reflect their experience to others (Broek, 2012).

This phase can be called the evaluating phase where inquirers feel relieved and happy as their research project is complete. Through this phase, students evaluate the importance of the inquiry based learning and its steps for raising their - learning to learn\| skills, identify the steps in their inquiry process, see the relations between their inquiry work done in faculty and their work or activities done outside of faculty and share their feelings about the process.

Finally, this phase helps students to reflect what way their knowledge has influenced their personal inquiry model and what they have learned about themselves as inquirers. The researcher asserts the role of this phase in evaluating the whole reading comprehension text in particular and Learning Process in general. The goal of this phase in the reflective writing lessons is to encourage students to determine their reflection of the ideas and concepts and evaluate their own progress. During this phase in the reflective writing lessons, students are requested to: record their new 24 vocabulary, give their opinion about the reflective essay and use new vocabulary to express their opinion. Furthermore, this phase leads students to like the reflective writing, overcome their writing apprehension and enjoy the learning process. Similarly, students are involved in making judgments about the text and thus the learning process come-up with reflection.

\section{Reflective Writing (RW)}

According to (Moon, 2004), reflection is a type of individual reactions to experiences, situation event or new knowledge it's a transformation stage where thinking or learning take 
place. There is neither a right nor a wrong way of reflective thinking there are just question to investigate.

\subsection{Definition of $\mathbf{R} \mathbf{W}$}

Reflective writing represents the visual presentation of reflection and the mental treatment of the internal problem solving activity. Reflective writing is more open than answering questions, unlike any other genre of writing, and allows the exploration of the connections between the inspiration found in the course and the experience of the writers (Crème, 2005).

According to (William K, Woolliams, M\&Spiraj 2012) reflective writing is an opportunity to show how the writer has gained experience and skills in his / her teaching room, or improved his / her practice by analyzing specific events and activities that he or she has gone past. This not only allows them to reflect on what they have done, but also to decide how authors will develop further.

Reflective writing could be defined according to the researcher as the reaction to experiences, views, events or new information, a reaction to thoughts and emotions, a way of thinking to discuss learning, an ability to acquire self-awareness, away from insight and deeper comprehension, and therefore a way to make sense of what the students read.

\subsection{The importance of RW}

Many scholars such as (Li, 2012; Choi, 2013; and Olanezhad, 2015) stress the importance of reflective writing, assuring that reflective writing has played a crucial role in human history. Writing equips students with tools to communicate their feelings, fears, goals, wishes, aspirations, and viewpoints. Writing fills the divide and links learners across boundaries and from distinct backgrounds. For EFL learners, writing is of utmost importance. As students are expected to use it as a platform for studying other classes, to plan home assignments and tasks, and ultimately to engage with their teachers, it is a survival ability. Writing is a requirement for achievement in all academic areas, and even in the workplace, however, it remains the most difficult language skill to acquire for first- and foreign language learners (Condon and Kelly-Riley2004) cited in (Umar \& Rathakrishnan, 2012).

Writing is an extremely complex process that requires a control over a wide variety of tasks ranging from letter formation and spelling to effective use of rhetorical patterns. The difficulty of writing is increased when students are required to write business documents such as letters, memos, proposals and reports. Actually, mastering business writing skills contributes to the success of business and to achieve customer's satisfaction. Poorly written documents may cause waste of time, money and efforts (Killeen, 2013).

Reflective writing prompt independent learning and help to take control of students learning and development, it helps the learner to organized his/her thoughts and responses in a structured way, assists the learner to achieve deep as opposed to surface learning and enables the learner to identity their personal strength and areas for development . 
In addition, (Connell \& Dyment, 2006) note that reflective writing gives students the ability to have more flexibility to articulate themselves and their learning, to focus on their personal growth and progress, to relate their field knowledge with their natural observation skills in class interactions and to establish an integrated connection with the more than human domain.

During reflective writing process the learners are provided and extra source of feedback from their instructor and improve the higher level critical thinking skills of analysis and assessment through writing on experiences case studies or an assigned event or problem. (Hackbert, 2002).

In addition, (Moon, 2007) highlighted different benefit of reflective writing.

1. Enhance the ability to reflect and improve learning quality.

2. Promote one's creative skills by making better use of intuitive under- standing.

3. Cultivate reflective and creative interactions within a group.

4. Improve professional practice.

5. Facilitate experiential learning.

6. Allow the learner's to understand their own learning process develop a questioning attitude.

7. Explore the self, personal meaning constructs and one's world view.

8. Expand the quality of learning in the form of critical thinking.

9. Promote active engagement in learning.

10. Promote problem solving skills.

\subsection{The main types of RW}

There are many types of reflective writing assignment including log's, diaries, reflective journals and critical incident account, reflective essays and reflective blogging, the reflective essay is the most commonly used in this research, the reflective essay is a mean that students are asked to draw on the theories they have read in order to share their own opinions on reading in a course that should include critical, educated, reflective and articulate answers to the statements presented in the lectures(pool 2001).

Writing a reflective essay is not merely a manner or putting words down on paper about the text but based on the next, the writer's read the text and then in a critical way he express his/her opinion about the text . Students are supposed to clarify the following issues when writing a reflective essay. Author's point of view, Author's purpose, Author's intended audience, Author's tone and author's writing style and the pattern of organizing the ideas in paragraphs can be arranged (Linh, 2010)

\subsection{Levels of Reflective Writing}

According to (Moon, 2004) there are four basic levels of reflective writing:

\section{Level 1 - Descriptive Writing}

It has no reflection. It can tell a story, but it is generated from one point of view at a time and normally one point at a time. Ideas appear to be related by the account / story series rather than by meaning. The account explains what occurred, referencing previous events sometimes, sometimes predicting the future, but all in the sense of an incident account. 


\section{Level 2 - Descriptive account with some reflection}

It is a detailed account that, while not displaying much reflection, signifies points for reflection. The basic account, in the manner mentioned above, is descriptive. Outside of the case, there is no incorporation of suggestions, appeal to different points of view or views to others, discussion and so on. The account is more than just a narrative. It concentrated in the events where Asking the questions makes it more of a descriptive account, but the omission of an effort to address the questions suggests that the incidents are not really examined. In (usually) isolated parts of the account, the questioning can tend to indicate a 'holding back from the incident'.

\section{Level 3 - Reflective writing (1)}

There is description, but it focuses on basic issues stressed for reflection. There might be a feeling of being mulled around the stuff. It is no longer a clear description of an incident, but it is undoubtedly reflective. There is evidence of external thoughts or knowledge and the material is exposed to reflection where this happens. Any research is seen in the report and the worth of investigating motivations or explanations for actions is acknowledged. Where applicable, the ability to be critical of the actions of oneself or others is accessible.

\section{Level 4 - Deep Reflective writing (2)}

Description now exists primarily for the method of reflection, shielding and explaining the context of the problems for reflection. There is ample evidence of stepping back from an incident and internal debate is being mulled over. The account demonstrates intense contemplation and provides an understanding that it will alter the frame of reference in which an incident is perceived. A metacognitive approach now only serves the process of reflection, covering the issues for reflection and noting their context. There is clear evidence of standing back from an event and there is mulling over and internal dialogue. The account shows deep reflection, and it incorporates a recognition that the frame of reference with which an event is viewed can change.

\subsection{Reflective writing and Inquiry based learning:}

The teacher should use any technique with different practices and media in teaching writing to strengthen the reflective writing skills of students. "Inquiry Based Learning" is one of these methods. Inquiry Based Learning is a collection of learning tasks and practices based on rational, objective and reflective reasoning to look for answers to challenges or problems (Sanjaya, 2010: 196) notes that students can understand the processes and the practice of writing by using Inquiry Based Instruction. By seeking the solution to the query of teachers or learners, they will learn how to produce ideas to create a good organization in writing, they will also improve their logical thought.

(Ash and Kluger-Bell, 2012) demonstrate that Inquiry Based Learning includes material and intellectual comprehension and growth, discipline skills and procedures, and mind attitudes and behaviors. Students will also improve their comprehension of the principles of grammar and mechanics. In order to finish or find alternate solutions, students should cooperate with their peers. They can also construct a strong sentence and substance by knowing the definition and discussing and revising their writing in-group, using proper spelling and punctuation. Therefore, the students are not only as an author, but also as a reader and editor. 
The inquiry process begins with one's own interest, curiosity or enthusiasm to appreciate an observation or solve a problem. (Schneider, 2012) reveals that the key phases or stages of the Inquiry are (1) Ask, this step focuses on a topic or subject that students are starting to identify. (2) Investigate, gather knowledge from students or groups of students, study, collect and manipulate tools, experiment, search, question,

(3) Create, the students start making links the information. They write them down in some kind of report, (4) Discuss, the students share their ideas with each other, and ask others about their own experiences and investigations, (5) Reflect, This step consists in taking time to look back. Think of the original issue again, the direction chosen, and the true assumptions. Inquiry-based learning may be used to develop reflective writing skills. It has natural steps, such as writing methods.

(Schneider, 2012) states that the steps of the Inquiry Based Learning as follows: Asking and investigating are prewriting step. Then, creating is during writing step. Discussing is rewrite steps. Reflecting as final step. Inquiry Based Learning can be used to evaluate students' problem in writing and the cause of them.

( Trianto ,2011: 166) notes that inquiry strategy is a group of procedures for teaching and studying that requires the capacity of all students to methodically, judgmentally, intellectually, objectively and analytically figure out and explain. It can be inferred that in writing a reflective essay, learners can think systematically, objectively, intellectually and analytically. Before writing, students should create an outline that can assist them to coordinate their writing. They should assume that their organization of writing was rational and systematic or not. They should care about correcting it into a rational and structured organization if it is not rational and structured.

(Ash and Kluger-Bell, 2012) indicate that Inquiry Based Learning offers material and intellectual comprehension and growth, skills and curriculum practices, and attitudes and habits of mind. Thus, by studying the example of sentences individually or in airs or in groups, students can improve their comprehension of the grammar principle. Moreover (Thirteen, 2012) argues that Inquiry Based Learning supports mental habits, it includes literary ideas and ideals for English. It suggests that students can grasp the idea of mechanics. It may also change their habits of mind that in writing they can follow the correct concept and use proper handwriting form in English subject matter.

\section{Reflection phases on the Process of inquiry based learning:}

Reflection phases are: planning, retrieving, processing, creating, sharing and evaluating which relate to affective and cognitive domains (Alberta Learning, 2004). These phases can be summed as shown below.

\section{Planning Phase}

Students can express a feeling of fascination or excitement about the subject at this phase. The entire project is used by students or the prosecutors as a mystery that needs to be solved. Students will begin with:

1- Realizing the general questions or problems that need to be investigated.

2- Searching for the data, knowledge, information and materials regarding the specific topic.

3- Defining the way to show the data to the target audience 
4- Proposing the criteria relevant to their research product and process evaluation. (Jonassen, 2000).

\section{Retrieving Phase}

In this phase, learners will be unaware of the amount of support they need to provide at the pre-focus stage. They may not know how to assess which material is meaningless or related to their investigation and may become irritated. Here is when it comes to the position of teacherfacilitator

\section{Processing Phase}

The inquirers have agreed on their "focus," they will be able to settle on their particular target and will be able to generate their thesis statement. The details may, however, be too "superficial" or too "in-depth" at this point and may also be confounding and inconsistent. Facilitators must then direct learners to compare, contrast and synthesize data in order to acquire the data from the right resources (Asselin, et al, 2003).

\section{Creating Phase}

The inquirers have a certain level of preparation at this stage and are able to arrange the information as well as create a presentation style. Nevertheless, in making the right one, they are unaware of their substance and require guidelines from teachers. Cooperative and interactive practices among learners may also be supported by teachers to work together in their innovative efforts to create the necessary tools, conversations and online projects. (Mc Gregory, 2003).

\section{Sharing Phase}

Inquirers can learn to engage and communicate their new knowledge with their target audience in a number of ways, such as by project presentations in this phase. Inquirers students also can develop constructive feedback and challenging strategies. Collaborative activities can be illustrated at this moment as the inquirers assist the other participants in their exchange by engaging as members of the audience (Asselin, et al , 2003).

\section{Evaluating Phase}

In order to obtain good results in the investigation, the teacher must have resources for The inquirers to reflect on the initial brainstorming session and evaluate the progress of their emphasis. In order to analyze their procedures and improvements, it is important that inspectors use learning resources such as rubrics and checklists. At this point, inquirers are also encouraged to work collaboratively to edit each other's offering. It is crucial to remember that judgment must not always focus or be more summative on the finished product as this can contribute to more plagiarism skills for inquirers (Mc Gregor, 2003).

\section{Writing Apprehension (WA)}

\subsection{Definition of WA}

According to (Chuo 2004), writing apprehension is a language-skill specific anxiety, unique to communicate with writing. It is a condition encountered by many people when presented with a task that involves writing. Different people have different degrees of anxiety about writing. People with high written apprehension avoid writing, and do so with great anxiety when required to compose. Writing apprehension is the propensity of the person to escape a situation that is considered to theoretically entail writing activities that may be followed by 
some form of appraisal. Extremely apprehensive authors treat writing as an experience that is unrewarding. As they expect to be negatively rated, they are afraid of judging their writings.

Writing apprehension is the individual's tendency to avoid a situation that is perceived to potentially require doing writing assignments that may be accompanied by some form of evaluation. Highly apprehensive writers view writing as an unrewarding experience. They fear the evaluation of their writing as they expect to be negatively rated. Consequently, in order to preserve their self-esteem, they stop publishing as much as they can. This impacts the standards of students of writing success and their ability to pursue potential writing courses (Salem, 2007).

(Reio, 2010) explaines that learners with a high degree of apprehension for writing avoid writing, particularly when it is to be evaluated. They expect unfavorable reviews of their written work and therefore stop lessons and assignments involving writing.

Writing apprehension is a psychological context disorder synonymous with reluctance, an inability to write or a reluctance to write. In a specific social context, students see writing as helpful and constructive, showing lower degrees of both written apprehension and resistance. Writing apprehension is negatively associated with self-efficacy, again making apprehension a good predictor of potential progress in writing and one that connects hypotheses of selfefficacy and resistance (Pappalardo, 2010). Writing apprehension has been described as a concept that is incredibly complex.it has become a crucial concern for the language learning of both native and non-native writers (Al-Ahmad, 2003). Also, (Daly, Vangelisti and Witte, 1988) described it as a writing-specific anxiety.

So it can be concluded that writing apprehension is "negative, anxious feelings towards writing and affected by many factors such as social, psychological, cognitive and academic factors and these factors affected on writing performance.

\subsection{The causes of WA}

Writing is an emotional and cognitive task, that is to say, when we are writing, we think and feel. Second language writing is also used as a nuanced system of the learner's educational, cultural and contextual forces and human characteristics, such as institutional criteria, parental or educational expectations, methods of teaching and evaluation, inspiration, attitude, self-confidence, and even gender and years in school (Cheng, 2002). The reasons why second language learners feel apprehended when writing can therefore be diverse and various, on the basis of previous research in the field of L2 writing as well as writing apprehension, but some general reasons ranging from highly personal (such as selfconfidence) to formal (such as classroom practices and teaching methods) can be established.

( Hassan , 2001) outlines some potential explanations for writing apprehension from a linguistic and cognitive viewpoint, such as weak ability growth, insufficient role models, lack of comprehension of the composition process, and an authoritative, teacher-centered, productbased teaching model. He emphasized that self-confidence is highly critical in deciding the 
affective response of learners to the role of writing. Some researchers have shown that no matter how competent or skilled people are in writing, whether they feel they are going to do badly or if they don't want to take stress writing classes, then their skills or capabilities matter little. (Holladay, 1981; cited by Hassan, 2001: 4). Another study has also shown that even students with high L2 writing skills may not generally view themselves as professional writers and may not be immune from writing apprehension (Cheng, 2002). Low selfconfidence or lack of trust in the achievement of L2 writing and writing achievement was therefore established as responsible for the experience of L2 writing apprehension among students.

Research has also stated that the teachers plays a basic role in cultivating students' notions about and attitudes toward writing (Palmquist and Young, 1992). A variety of studies demonstrated how the writing apprehension of teacher influenced the learners teaching activities, again in L1 environments. (Claypool's, 1980) research, for instance, analyzed how the writing apprehension of secondary school teachers was correlated to the extent at which they performed writing tasks. She reported a negative relationship between the writing apprehension of teachers and the amount of writing assignments they made. (Gere, Schuessler and Abbott, 1984) explained in another study how the fear of teachers' learning was related to what they found meaningful and related to teaching and writing process. The findings found that teachers with high apprehension of writing were harsher than those with low apprehension of style and self-expression. In addition, a negative link was found between the levels of teachers writing apprehension and their use of a variety of teaching writing instructional techniques.

Daly and his peers published two studies explaining the relationship between the teachers' writing apprehension and their activities in the classroom (Daly, Vangelisti, and Witte, 1988). The findings of these two studies showed that the fear of writing by professors influenced the process they analyzed the written products of students. Low apprehension teachers tended to be less constrained by strict guidelines compared to teachers with high apprehension, to stress free thinking and initiative more and to care less about technical structure. The writing apprehension of teachers was also discovered to be adversely linked to their use of tests and tasks that involved writing.

It could be concluded, based on the above findings of the tests, that writing apprehension

will similarly influence the activities of EFL postgraduate students and their attitudes towards writing instruction. Thus, by learning about their level of apprehension and the underlying causes, teachers can assist the students to reduce their writing apprehension.

Other studies have shown the key factors influencing writing apprehension, as (Al-Ahmad, 2003) correlates complexity with the absence of formal definitions on the elements of writing apprehension in the usage of apprehension terminology (e.g. the affective and cognitive method, the intellectual sense, and the personal views of the writer). The outcome of this research revealed that gender differences had no major role in writing apprehension for all 
factors except feedback, among various factors of writing apprehension such as (affective, emotional, linguistics, teaching practice, actions of students, and feedback).

Another research found that Jordanian undergraduate students at Yarmouk University, who were significant in the third year of English language and literature, have a high degree of writing apprehension (Al-Sawalha and Chow, 2012). (Huwari \& Al-Shboul, 2015) at Utara Malaysia University conducted the first overseas survey of Jordanian $\mathrm{PhD}$ students. To get their thoughts on writing discomfort, the researchers interviewed $21 \mathrm{PhD}$ students. Three key trends were found in terms of the consequences of writing apprehension, such as personal impact, social affect, and intellectual impact (Huwari \& Al-Shboul, 2015), Although four major trends were found in their analysis in terms of the causes of writing apprehension, which are Lack of awareness in the framework of English, Negative attitude towards learning, previous negative learning experience, and Insufficient expertise of academic writing (AlShboul \& Huwari, 2015). Furthermore, researchers such as (Huwari and Noor Hashima, 2011) argue that it is important to examine writing apprehension among Arabic EFL learners in particular.

\subsection{Methods to Reduce WA}

There are many ways in which learners can reduce their writing apprehension. (Stapa, 1998) discusses that studies focus on minimizing apprehension in writing and describes four main explanations for anxiety in writing. First of all, for writers to excel in fiction, a specific level of apprehension or anxiety is imperative. Some students, though, exhibit a higher than average degree of writing apprehension that can negatively affect their writing and view the poor writer's performance. Second, for the reason of receiving constructive reinforcement to inspire them, students indicate a desire to improve writing skills. Third, when teachers ask them to write a reflective essay, students normally experience apprehension when writing.

Teachers note that apprehension in the students' writing, so they may change their teaching instruction to reduce this apprehension. The teachers would work on correcting spelling, punctuation, and grammar. For ESL / EFL learners, this is particularly true. Students from Midwestern University encountered published apprehension. This apprehension could effect on their ability to write (Hanna, 2010).

There were some methods proposed by (Reeves, 1997) to help students reducing their writing apprehension. The following are these new techniques:

(1) Practice writing more,

(2) Discouraging voice appropriation,

(3) Listening to anxious writer,

(4) Expressing your own communicating experiences,

(5) Discovering trends in the failures of others, 
(6) Contextualizing and customizing,

(7) During the drafting processes of the meeting,

(8) Consult with students for appraisal requirements,

(9) Mentor peers for successful response,

(10) Validate intrapersonal communication: self-talk,

(11) Be mindful of potential gender gaps,

(12) Vary writing styles,

(13) Track behaviors,

(14) Incorporate group conversation,

(15) Talk about authors you admire,

(16) Give public readings and attend them;

(17) Participate writing. The reduction of written apprehension among students has been recorded to not be entirely the responsibility of the instructor as students still have a part in it (Clark, 2005).

(Daud and Kassim, 2005) propose several techniques that will help students reduce their writing apprehension:

(1) Instructors should concentrate more on the way they teach,

(2) Instructors motivate students to complete their writing exercise or assist them to find the answer to the given problem or topic,

(3) Instructors should use different methods to develop the language of students,

(4) Instructors should teach writing as fluency rather than precision,

(5) Instructors should ask students to correct the errors on their own.

(Abu Shawish and Atea, 2010) offer a description of the interventions used in second / foreign language literature on writing apprehension:

1. Teachers should provide students with a writing task that is not marked out of the fear of being adversely judged by the students (Clark, 2005).

2. Feedback (Borich, 2004; Clark, 2005; Grabe and Kaplan, 1995; Kurk and Atay, 2007) should be given in a positive way. 
3. Writing can be a phase of teaching (Clark, 2005; Rankin-Brown, 2006; Grabe \& Kaplan, 1995).

4. Students can correct their errors (Bernstein, 1978; Wachholz \& Etheridge, 1996; Reeves, 1997).

5. Giving a time fit with free writing activities (Boice, 1993; Dickson-Markman, 2001; Stover, 1988; Veit, 1980).

6. Teaching writing concurrently to reduce writing apprehension (Daud et al., 2005).

\section{Context of the problem}

Most EFL students hesitate to write a paragraph or essay because they have little experience, little faith, no concepts, a nominal vocabulary, deformed syntax, and possibly vague punctuation thoughts, they can't generate ideas and fear of making errors. So that students should then do more practice in order to learn to write.

The researcher observed that the EFL postgraduate students at the Faculty of Specific Education face many difficulties in reflective writing skills and have a high level of writing apprehension. This is supported by the aforementioned studies and with a pilot study the researcher conducted to document the problem of the study including (30) EFL postgraduate students at the department of curriculum and instruction in the second term of the academic year 2018-2019. The students were given EFL reflective writing test and a writing apprehension test.

The results of the pilot study test illustrated that the percentage of the students' responses to the reflective writing test was less than $50 \%$, this result means that EFL post graduate students face difficulties in reflective writing skills such as they can't express their onions Cleary, have no evidence for these opinions, can't make compare and contrast in writing a reflective essay and also have no critical thinking in discussing a topic. And their responses level to the writing apprehension scale was more than $80 \%$ this means that they have high level in writing apprehension.

So, it is important to encourage students to be familiar with writing and how it works as an instrument of learning and self-expression. Instructors should also give the students the opportunities to share their own experiences to develop their confidence and autonomy in writing. (Helwa, 2013) stated that students should be encouraged to write cohesively and coherently. Teachers' feedback has an important role in developing and enhancing the quality of students' written essays and decreasing writing apprehension.

\section{Statement of the problem:}

Despite the reflective writing skills have an important role for the EFL post graduate students enrolled in first year Special Diploma, Dept. of curriculum and EFL instruction at Zagazig faculty of Specific Education, they have difficulties in writing reflective essays. And 
they also have high level of writing apprehension. The present research aims at examining the effectiveness of inquiry based learning program in developing EFL reflective writing skills and reducing writing apprehension among post graduate students at Faculty of Specific Education.

\section{Questions of the study:}

1. What are the main features of a proposed program based on inquiry learning that may be used for developing EFL reflective writing skills and decreasing writing apprehension among postgraduate students at Faculty of Specific Education, curriculum and EFL instruction department?

2. How far is the proposed program effective for developing EFL reflective writing skills among postgraduate students at Faculty of Specific Education?

3. How far is the proposed program effective for reducing writing apprehension among postgraduate students at Faculty of Specific Education?

\section{Hypotheses of the Study:}

Based on the related studies and research questions the following hypotheses were formulated:

1. There is a statistically significant difference between the mean score of the experimental group and that of the control group in the post- test of EFL overall reflective writing skills in favor of the experimental group.

2. There is a statistically significant difference between the mean score of the experimental group and that of the control group in the post- test of EFL overall reflective writing sub-skills in favor of the experimental group.

3. There is a statistically significant difference between the mean score of the experimental group and that of the control group in the post- test of writing apprehension test in favor of the control group.

4. The inquiry based learning program is effective in developing reflective writing skills.

\section{Method}

5. The inquiry based learning program is effective in reducing writing apprehension.

\section{Participants}

The study participants were thirty students $(\mathrm{N}=30)$. They were chosen randomly from postgraduate students, first year diploma enrolled in curriculum and EFL instruction Dept. at the Faculty of Specific Education, Zagazig University, Egypt. They were divided into two groups: an experimental group $(\mathrm{N}=15)$ (taught via the proposed inquiry based learning program) and a control group $(\mathrm{N}=15)$ (received regular method). To make sure that both groups were equivalent in the EFL reflective writing skills, the EFL reflective writing skills test and writing apprehension scale were administered to the control group and the experimental group before applying the program. Mean, standard deviation and " $t$ " value of the two groups were computed. 
Table (1): Pre t-test for the control and the experimental groups in reflective writing skills.

\begin{tabular}{|c|c|c|c|c|c|c|c|}
\hline Skill & Group & $\mathbf{N}$ & $\mathbf{M}$ & S.D & D. $\mathrm{f}$ & t-value & Sig \\
\hline \multirow[b]{2}{*}{ 1- Giving opinion } & Control & 15 & 1.27 & .458 & \multirow{12}{*}{28} & .418 & $.679 *$ \\
\hline & Experimental & 15 & 1.20 & .414 & & & \\
\hline \multirow[b]{2}{*}{ 2-Providing Evidence } & Control & 15 & 1.20 & .414 & & \multirow[t]{2}{*}{.807} & \multirow[t]{2}{*}{$4.26^{*}$} \\
\hline & Experimental & 15 & 1.33 & .488 & & & \\
\hline \multirow[t]{2}{*}{ 3-Make Comparison } & Control & 15 & 1.67 & .724 & & \multirow[t]{2}{*}{.871} & \multirow[t]{2}{*}{$.392 *$} \\
\hline & Experimental & 15 & 1.47 & .516 & & & \\
\hline \multirow[t]{2}{*}{ 4-Critical Thinking } & Control & 15 & 1.27 & .458 & & \multirow[t]{2}{*}{.418} & \multirow[t]{2}{*}{$.679 *$} \\
\hline & Experimental & 15 & 1.20 & .414 & & & \\
\hline \multirow{2}{*}{$\begin{array}{l}\text { 5- Show depth of } \\
\text { Reflection }\end{array}$} & Control & 15 & 1.33 & .617 & & \multirow[t]{2}{*}{.695} & \multirow[t]{2}{*}{$.493^{*}$} \\
\hline & Experimental & 15 & 1.20 & .414 & & & \\
\hline \multirow{2}{*}{$\begin{array}{l}\text { Overall EFL reflective } \\
\text { writing skills }\end{array}$} & Control & 15 & 6.73 & .884 & & \multirow[t]{2}{*}{.596} & \multirow[t]{2}{*}{ ¿10* } \\
\hline & Experimental & 15 & 6.40 & .828 & & & \\
\hline
\end{tabular}

Pre-testing results in table (1) above shows that t-value (.596) is not significant at the level of 0.01. So, there was no significant difference between the control and the experimental group in EFL reflective writing skills in pre-test. This indicates homogeneity of the two groups. This is to illustrate that the two groups were almost at the same level of performance in the EFL reflective writing skills. The results of the pre- administration revealed that the participants had low average in reflective writing.

Table ( 2): Pre t-test for the control and the experimental groups in writing apprehension scale in the pre administration.

\begin{tabular}{|c|c|c|c|c|c|c|c|}
\hline Level of agree & Group & $\mathbf{N}$ & $\mathbf{M}$ & S.D & D. $\mathrm{f}$ & t-value & sig \\
\hline \multirow[b]{2}{*}{ Strongly Agree } & Control & 26 & 16.92 & 18.219 & & \multirow{2}{*}{.521} & \multirow[t]{2}{*}{$.604 *$} \\
\hline & Experimental & 26 & 14.50 & 15.158 & \multirow{9}{*}{50} & & \\
\hline \multirow[b]{2}{*}{ Agree } & Control & 26 & 14.32 & 15.981 & & \multirow[t]{2}{*}{.310} & \multirow[t]{2}{*}{$.758^{*}$} \\
\hline & Experimental & 26 & 13.00 & 12.384 & & & \\
\hline \multirow[t]{2}{*}{ Uncertain } & Control & 26 & 1.96 & 2.236 & & \multirow[t]{2}{*}{.975} & \multirow[t]{2}{*}{$.334 *$} \\
\hline & Experimental & 26 & 2.54 & 2.024 & & & \\
\hline \multirow[t]{2}{*}{ Disagree } & Control & 26 & 14.92 & 16.495 & & \multirow[t]{2}{*}{.633} & \multirow[t]{2}{*}{$.530^{*}$} \\
\hline & Experimental & 26 & 12.38 & 12.106 & & & \\
\hline \multirow{2}{*}{ Strongly Disagree } & Control & 26 & 17.50 & 19.962 & & \multirow[t]{2}{*}{.166} & \multirow[t]{2}{*}{$.869^{*}$} \\
\hline & Experimental & 26 & 18.38 & 18.431 & & & \\
\hline
\end{tabular}

Pre-testing results in Table (2) above shows that there was no significant difference at the level of 0.01 between the control and the experimental group in EFL writing apprehension scale in pre-administration, so the study groups were at the same level.

\section{Study Instruments}

In order to fulfill the purposes of the study, the following instruments were designed.

\section{A. EFL Reflective Writing Skills Test:}

The EFL reflective writing skills test was prepared by the researcher to measure reflective writing skills among postgraduate students, curriculum and EFL instructions Department, at Faculty of Specific Education, Zagazig University, Egypt. It was used as a pre-posttest. The test consisted of four questions (writing reflective essays) suitable for students' level and 
background knowledge (see appendix B). The students are required to write reflective essays to test giving opinion, providing evidence to support opinions, making comparison, testing critical thinking and showing depth of reflection. The time of the EFL reflective writing skills test lasted two hours. It was counted through getting the mean between the fastest student and the lowest one in answering the test questions.

The test was marked by the researcher through using a rubric prepared -by her. The rubric consists of five parts; each part has four items ranging from "4" marks to "1" mark. The students were given "4" marks when their performance is high and "1" mark when their performance is low (see appendix C).

\section{B. Writing Apprehension Test (WAT)}

Daly and Miller writing apprehension test (WAT) was adopted to assess the students' level of writing apprehension (see Appendix D). The WAT contains 26 statements using a five-point Likert scale with responses from strongly agrees to strongly disagree. The high reliability estimate measured with Cronbach's alpha coefficient ranged from .89 to .94 .Daly and Miller's WAT has been used extensively and is considered an accurate tool for measuring students' writing apprehension. As scores get higher, the level of apprehension decreases. The converse is true as scores get lower, the score for writing apprehension increases. The range is from 46 to 96. Students who have high levels of apprehension often lack confidence that they can perform well even if they have the necessary skills. Using the WAT as a pre and post- test to determined changes in the students' level in writing apprehension.

\section{Determining the Validity of the Research Instruments:}

The EFL reflective writing skills test, the Dally and Miller writing apprehension test (WAT) were applied to a member of the jury (see Appendix E) to assess the quality of the resources in terms of specific directions, objects and their suitability for the level of the students. They suggested that the guidelines for the assessments were straightforward and relevant for the degree and subject experience of the students.

Therefore, the tests were valid measure of reflective writing skills and writing apprehension (Face Validity).To ensure the content validity of the tests, they were developed in the light of a systematic and accurate of literature and previous studies. This accurate and systematic review determined the general form of the tests, their form of questions and how they should be corrected. Therefore, the content of the tests was representative of the skills that were intended to be measured. Thus, the tests were valid and having a content validity.

Determining the reliability of the study instruments using the test-retest process, the reliability of the instruments was calculated. The instruments were prescribed at the Faculty of Specific Education, Zagazig University, Egypt, to a sample of postgraduate students enrolled in the curriculum and EFL teaching. Then they were administered again after two weeks to the same sample. At the 0,01 mark, the Pearson correlation between the two administrations was (0.88). The tools were, thus, reliable. 


\section{A. The inquiry based learning program}

For achieving the aims of the study, the researcher purposed inquiry based learning program. After assessing post graduate students' enrolled in curriculum and EFL instructions department at Faculty of Specific Education, Zagazig University, Egypt reflective writing skills and writing apprehension, the experimental group students were required to attend the program (See Appendix G).

\section{Objectives of the inquiry based learning program:}

Developing EFL reflective writing skills and reducing writing apprehension among postgraduate students in curriculum and EFL instruction department at Faculty of Specific Education, Zagazig University, Egypt were the main aims of this study.

\section{Content of the Program}

The topics of the program were selected from books and studies enriched with topics that encourage students to write a reflective essay and help them to decrease their writing apprehension. All materials contained a variety of topics, pictures and stories prepared for improving reflective writing skills and reducing writing apprehension.

\section{The Program Framework}

The treatment began on $20^{\text {th }}$ March 2019 until $20^{\text {th }}$ May 2019. The students were met for two hours twice a week for eight weeks (16 sessions). Week 1 was used for pre-testing and week 8 was used for post testing. Each session included the following points: introduction, objectives, procedures, the role of the instructor and student and finally the performance. During the instructional procedures, different sessions had different learning objectives and different methods were applied.

The Researcher herself taught the program to the experimental group. Sixteen instructional sessions lasted for eight weeks and each session lasted two hours. At the start of the proposed program, the researcher presented what they would do to the students. Second, she told them about the program's goals and what they're going to learn by engaging in the program (Goal Setting). Afterwards she told them about the value of writing skills in general and then EFL reflective writing skills and writing apprehension. Then she started to incorporate the inquirybased learning and its relevance for language learning and reflective writing skills and writing apprehension at EFL. The remainder of the program were teaching sessions after the launch of the program, in which the EFL incorporated reflective writing skills and writing apprehension.

The researcher informed students the goals of the session at the beginning of each session, the role of the researcher, the role of the student, the instructional materials to be used, the tasks to be done and ways to measure their progress.

The researcher gave students some activities related to what they had learned at the end of each session to make sure they mastered the skills in each session (formative assessment). 
The researcher measured the achievement of the students after introducing the curriculum at the end of the program using the EFL reflective writing skills test and writing apprehension test (summative evaluation).

\section{Findings of the Study}

\section{A .Findings of the Quantitative Analysis}

The findings are stated as follows: Before experimentation, (control group and the experimental group) were pre-tested to make sure that all groups were equal in reflective writing skills and writing apprehension. The statistical package for social science program (SPSS Ver.26) was used to calculate the differences between the mean scores of the control and experimental group on the pre and the post testing. The researchers used t-test to calculate the t-values for testing the differences between the mean scores of the study groups.

\section{First Hypotheses:}

"There is statistically significant differences between the mean scores of the experimental group and the control groups in the post-administration of the overall reflective writing skills test and its sub-skills in favor of the experimental group."

To verify this hypothesis, the researcher used the Independent sample t-test to compare the mean scores of the experimental group students who used An inquiry based learning program with those of the control group students who used the traditional method, in the post-test. The results are presented in the following table.

Table (3): post t-test for the control and the experimental groups in reflective writing skills.

\begin{tabular}{|c|c|c|c|c|c|c|c|}
\hline Skill & Group & $\mathbf{N}$ & $\mathbf{M}$ & S.D & D. $f$ & t-value & sig \\
\hline \multirow[b]{2}{*}{ 1- Giving opinion } & Control & 15 & 1.33 & .488 & \multirow{12}{*}{28} & \multirow[t]{2}{*}{11.993} & \multirow[t]{2}{*}{$0.000^{*}$} \\
\hline & Experimental & 15 & 3.53 & .516 & & & \\
\hline \multirow[b]{2}{*}{ 2-Providing Evidence } & Control & 15 & 1.13 & .352 & & \multirow[t]{2}{*}{9.408} & \\
\hline & Experimental & 15 & 3.20 & .775 & & & \\
\hline \multirow[t]{2}{*}{ 3-Make Comparison } & Control & 15 & 1.27 & .458 & & 11.575 & $0.000^{*}$ \\
\hline & Experimental & 15 & 3.60 & .632 & & & \\
\hline \multirow[t]{2}{*}{ 4-Critical Thinking } & Control & 15 & 1.13 & .352 & & \multirow[t]{2}{*}{9.420} & \multirow[t]{2}{*}{$0.000^{*}$} \\
\hline & Experimental & 15 & 3.13 & .743 & & & \\
\hline \multirow[t]{2}{*}{ 5- Show depth of Reflection } & Control & 15 & 1.07 & .258 & & \multirow[t]{2}{*}{10.150} & \multirow[t]{2}{*}{$0.000^{*}$} \\
\hline & Experimental & 15 & 3.27 & .799 & & & \\
\hline \multirow{2}{*}{$\begin{array}{l}\text { Overall EFL reflective } \\
\text { writing skills }\end{array}$} & Control & 15 & 5.93 & .961 & & \multirow[t]{2}{*}{23.109} & \multirow[t]{2}{*}{$0.000^{*}$} \\
\hline & Experimental & 15 & 16.73 & 1.534 & & & \\
\hline
\end{tabular}

* Significant

The table above indicates that the mean scores of the experimental group students are higher than those of the control group in overall reflective writing skills and its sub-skills, where tvalue is, (23.109) for overall reflective writing skills, which is significant at 0,01 level of significance. Therefore, this hypothesis was confirmed. These differences can be attributed to an inquiry based learning program. 


\section{Second Hypotheses:}

"There is a statistically significant differences between the mean scores of the experimental group in the pre-and post-administrations of the overall EFL reflective writing skills test and its sub-skills in favor of the post-administration"

To verify this hypothesis, the researcher used the paired sample t-test to compare the mean scores of the experimental group who used an inquiry based learning program in the pre and post-test. The following table includes the results.

Table (4): post t-test results of the experimental group in overall reflective writing skills.

\begin{tabular}{|c|c|c|c|c|c|c|c|}
\hline Skill & Group & $\mathbf{N}$ & M & S.D & D. $f$ & t-value & sig \\
\hline \multirow{2}{*}{ 1- Giving opinion } & Pre & 15 & 1.27 & .458 & \multirow{12}{*}{28} & \multirow[t]{2}{*}{14.789} & \multirow{2}{*}{$0.000^{*}$} \\
\hline & Post & 15 & 3.53 & .516 & & & \\
\hline \multirow[b]{2}{*}{ 2-Providing Evidence } & Pre & 15 & 1.20 & .414 & & \multirow[t]{2}{*}{10.247} & \\
\hline & Post & 15 & 3.20 & .775 & & & \\
\hline \multirow[t]{2}{*}{ 3-Make Comparison } & Pre & 15 & 1.67 & .724 & & \multirow[t]{2}{*}{12.614} & \multirow[t]{2}{*}{$0.000^{*}$} \\
\hline & Post & 15 & 3.60 & .632 & & & \\
\hline \multirow[t]{2}{*}{ 4-Critical Thinking } & Pre & 15 & 1.27 & .458 & & \multirow[t]{2}{*}{14.000} & \multirow[t]{2}{*}{$0.000^{*}$} \\
\hline & Post & 15 & 3.13 & .743 & & & \\
\hline \multirow[t]{2}{*}{ 5- Show depth of Reflection } & Pre & 15 & 1.33 & .617 & & \multirow[t]{2}{*}{9.374} & \multirow[t]{2}{*}{$0.000^{*}$} \\
\hline & Post & 15 & 3.27 & .799 & & & \\
\hline \multirow{2}{*}{$\begin{array}{ccc}\begin{array}{c}\text { Overall } \\
\text { writing skills }\end{array} & \text { reflective } \\
\end{array}$} & Pre & 15 & 6.73 & .884 & & \multirow[t]{2}{*}{30.896} & \multirow[t]{2}{*}{$0.000^{*}$} \\
\hline & Post & 15 & 16.73 & 1.534 & & & \\
\hline
\end{tabular}

* Significant

The table above indicates that the mean scores of the experimental group students in posttest are higher than those in the pre-test in overall reflective writing skills and its sub-skills, where t-value is, (30.896) for overall reflective writing skills, which is significant at 0,01 level of significance. Therefore, this hypothesis was confirmed. These differences can be attributed to an inquiry based learning program.

\section{Third Hypotheses:}

"There is a statistically significant differences between the mean scores of experimental and the control groups in the post-administration of the overall writing apprehension scale in favor of the experimental group"

To verify this hypothesis, the researcher used the Independent sample t-test to compare the mean scores of the experimental group students who used An inquiry based learning program with those of the control group students who used the traditional method, in the postadministration overall writing apprehension. The results are presented in the following table. 
Table (5): post t-test for the control and the experimental groups in EFL reflective writing apprehension scale in pre administration.

\begin{tabular}{|c|c|c|c|c|c|c|c|}
\hline Level of agree & Group & $\mathbf{N}$ & $\mathbf{M}$ & S.D & D. f & t-value & sig \\
\hline \multirow[b]{2}{*}{ Strongly Agree } & Control & 26 & 17.92 & 18.041 & \multirow{10}{*}{50} & \multirow[t]{2}{*}{4.320} & \multirow[t]{2}{*}{$0.00 *$} \\
\hline & Experimental & 26 & 2.47 & 2.782 & & & \\
\hline \multirow[b]{2}{*}{ Agree } & Control & 26 & 14.32 & 15.342 & & \multirow[t]{2}{*}{1.372} & \multirow[t]{2}{*}{$0.00 *$} \\
\hline & Experimental & 26 & 9.46 & 8.882 & & & \\
\hline \multirow[t]{2}{*}{ Uncertain } & Control & 26 & 1.50 & 1.749 & & 1.309 & $0.00 *$ \\
\hline & Experimental & 26 & .92 & 1.412 & & & \\
\hline \multirow[t]{2}{*}{ Disagree } & Control & 26 & 14.92 & 16.260 & & \multirow[t]{2}{*}{2.372} & \multirow[t]{2}{*}{$0.00 *$} \\
\hline & Experimental & 26 & 6.77 & 6.550 & & & \\
\hline \multirow[t]{2}{*}{ Strongly Disagree } & Control & 26 & 17.31 & 19.811 & & \multirow[t]{2}{*}{3.150} & \multirow[t]{2}{*}{$0.00^{*}$} \\
\hline & Experimental & 26 & 4.81 & 4.128 & & & \\
\hline
\end{tabular}

*significant

Post-testing results in Table (6) shows that there were significant differences at the level of 0.01 between the control and the experimental group in EFL writing apprehension scale in post-administration.

\section{Fourth Hypotheses:}

"There is a statistically significant differences between the mean scores of experimental group in the pre and post-administration of the overall writing apprehension scale in favor of the post-administration".

Table (6): post t-test for the experimental groups pre and post in the writing apprehension scale in post administration.

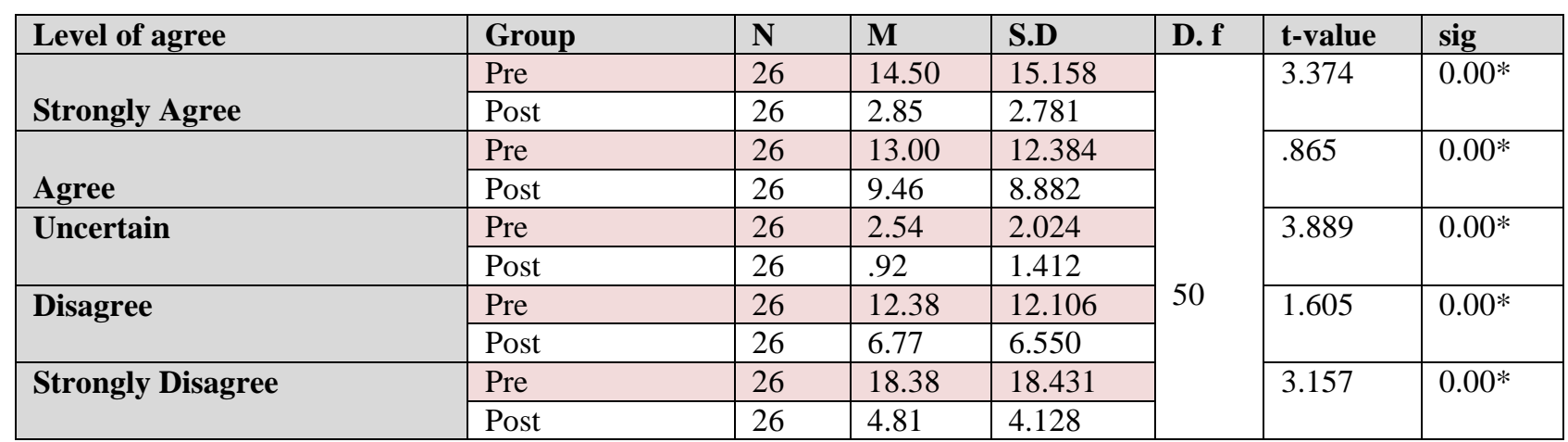

*significant

Table (6) shows that there were statistically significant differences between the mean scores of experimental group in the pre and post-administration of the overall writing apprehension scale in favor of the post-administration. This means that the inquiry based learning program is effective in reducing the students' level in writing apprehension.

\section{Fifth Hypotheses:}

"Inquiry based learning program is effective in developing the EFL reflective writing skills". 
Table (7): The effect size of the experimental group in EFL reflective writing skills as a whole in the pre and the post test.

\begin{tabular}{|c|c|c|c|c|c|c|c|}
\hline Skill & Test & $\mathbf{N}$ & $\mathbf{M}$ & S.D & t-value & $\begin{array}{l}\text { Eta } \\
\text { square }\end{array}$ & $\begin{array}{l}\text { Effect } \\
\text { size }\end{array}$ \\
\hline \multirow[b]{2}{*}{ 1- Giving opinion } & Pre & 15 & 1.27 & .458 & \multirow[t]{2}{*}{14.789} & \multirow[t]{2}{*}{.853} & 2.408 \\
\hline & Post & 15 & 3.53 & .516 & & & high \\
\hline \multirow{2}{*}{ 2-Providing Evidence } & Pre & 15 & 1.20 & .414 & \multirow[t]{2}{*}{10.247} & \multirow[t]{2}{*}{.735} & 1.665 \\
\hline & Post & 15 & 3.20 & .775 & & & high \\
\hline \multirow{2}{*}{ 3-Make Comparison } & Pre & 15 & 1.67 & .724 & \multirow[t]{2}{*}{12.614} & \multirow[t]{2}{*}{.684} & 1.471 \\
\hline & Post & 15 & 3.60 & .632 & & & high \\
\hline \multirow[t]{2}{*}{ 4-Critical Thinking } & Pre & 15 & 1.27 & .458 & \multirow[t]{2}{*}{14.000} & \multirow[t]{2}{*}{.710} & 1.564 \\
\hline & Post & 15 & 3.13 & .743 & & & high \\
\hline \multirow{2}{*}{$\begin{array}{l}\text { 5- Show depth of } \\
\text { Reflection }\end{array}$} & Pre & 15 & 1.33 & .617 & \multirow[t]{2}{*}{9.374} & \multirow[t]{2}{*}{.663} & 1.402 \\
\hline & Post & 15 & 3.27 & .799 & & & high \\
\hline \multirow{2}{*}{$\begin{array}{l}\text { Overall EFL reflective } \\
\text { writing skills }\end{array}$} & Pre & 15 & 6.73 & .884 & \multirow[t]{2}{*}{30.896} & \multirow[t]{2}{*}{.945} & 4.145 \\
\hline & Post & 15 & 16.73 & 1.534 & & & high \\
\hline
\end{tabular}

Table (7) indicates that the effect size of the experimental group students in the post test are greater and higher than those of the pre-scores in overall EFL reflective writing skills, where the effect size is (4.145) for overall EFL writing skills which is significant at 0, 01 level of significance. Therefore, this hypothesis was confirmed. These differences can be attributed to the Inquiry based learning program.

Sixth Hypotheses: "Inquiry based learning program is effective in reducing the writing apprehension".

Table (8) The effect size of the experimental group in writing apprehension as a whole in the pre and the post test.

\begin{tabular}{|c|c|c|c|c|c|c|c|}
\hline Level of agree & Group & $\mathbf{N}$ & M & S.D & t-value & $\begin{array}{l}\text { Eta } \\
\text { square }\end{array}$ & $\begin{array}{l}\text { Effect } \\
\text { size }\end{array}$ \\
\hline \multirow[t]{2}{*}{ Strongly Agree } & Pre & 26 & 14.50 & 15.158 & \multirow[t]{2}{*}{3.374} & \multirow[t]{2}{*}{.229} & 5.449 \\
\hline & Post & 26 & 2.85 & 2.781 & & & high \\
\hline \multirow[t]{2}{*}{ Agree } & Pre & 26 & 13.00 & 12.384 & \multirow[t]{2}{*}{.865} & \multirow[t]{2}{*}{.027} & 1.665 \\
\hline & Post & 26 & 9.46 & 8.882 & & & high \\
\hline \multirow{2}{*}{ Uncertain } & Pre & 26 & 2.54 & 2.024 & \multirow{2}{*}{3.889} & \multirow[t]{2}{*}{.182} & 4.716 \\
\hline & Post & 26 & .92 & 1.412 & & & high \\
\hline \multirow{2}{*}{ Disagree } & Pre & 26 & 12.38 & 12.106 & \multirow[t]{2}{*}{1.605} & \multirow[t]{2}{*}{.080} & 2.948 \\
\hline & Post & 26 & 6.77 & 6.550 & & & high \\
\hline \multirow[t]{2}{*}{ Strongly Disagree } & Pre & 26 & 18.38 & 18.431 & \multirow[t]{2}{*}{3.157} & \multirow[t]{2}{*}{.212} & 5.186 \\
\hline & Post & 26 & 4.81 & 4.128 & & & high \\
\hline
\end{tabular}

Table (8) indicates that the effect size of the experimental group students in the post test are lower and smaller than those of the pre-scores in overall writing apprehension scale. Therefore, this hypothesis was confirmed. These differences can be attributed to the Inquiry based learning program.

\section{Results and Discussion:}

The research findings supported hypotheses of the research. According to statistical data, the inquiry based learning program was more effective than regular instruction method in 
enhancing EFL reflective writing skills and decreasing writing apprehension level of EFL postgraduate students .

The basic objective of this research is to develop EFL postgraduate students' reflective writing and decreasing their writing apprehension in curriculum and EFL instruction section at the faculty of Specific Education, Zagazig University through using inquiry based learning program. The program included variety of tasks, exercises and activities for assisting students develop their reflective writing skills and decreasing their writing apprehension. The results of the research investigated that, the program proved to be statistically and educationally significant in achieving the main objectives of this research. So these significant improvements and modification can be attributed to a number of causes related to the nature of inquiry based learning program as follows: motivating participants, increasing communication and interaction among participants, providing an opportunity to work in groups, improving critical , analytical and creative thinking, enriching learning environments, developing learning activities, and providing students with a sense of community and engagement in their learning process.

The main components of effective inquiry may assist skilled learners to:

1- See trends and definitions that are not clear to those that are unskilled.

2- Have in-knowledge of their subject matter in full.

3- Have their information designed to be available, transferable and relevant quickly.

4- Acquire, with little effort, new knowledge relevant to their content area.

Results of this research are discussed with reference to the variables (reflective writing and writing apprehension) as shown below.

\section{Concerning the development of EFL reflective writing:}

The participants' advance in the post test of the reflective writing skills test could be attributed to the use of inquiry based learning program. This program increased students' motivation to write an acceptable reflective essay using reflective writing skills. As a result, students are encouraged to be responsible for their own work, through participating. Students were given the rights to express their own opinions freely, select the topics or tasks in writing classes.

Therefore, it is essential for the students to be familiar with writing and how it works as an instrument of learning and self-expression so they can enhance their reflective writing skills.

There are many important improvements in reflective writing for all participants in the experimental group as follows:

1. They could give opinions. The students were expected to provide their own point of views, based on reading material.

2. They could provide evidence to support these opinions. The students were expected to provide different point of view and compare them to his/her own. 
3. They could make comparisons. Student hah the ability to give unexpected answers to the questions.

4. They become critical thinking. The student was expected to elaborate his/her points, and use techniques such as questioning, researching, comparing, and analyzing.

5. They could show depth of reflection. The student was expected to provide a reflection to what he/she read and reflect it in their writing.

6. The interpretation of students will shift from the general to the more precise and specified criteria of a query.

7. If they have a better grasp of the information system and how to search for similar references, students would be able to gain knowledge more effectively.

8. From their encounters and through social connections, students systematically develop their skills.

9. Via personal observations and explorations, as well as encounters with artifacts and other individuals, student inquirers are inspired to pursue new concepts and understandings.

10. Learning is increased by the ability for students to participate in events, contexts and with actual people in real life.

Inquiry-based learning increases the reflective writing abilities of students while the approach enhances the mental practices of students such as comprehension, analysis, appraisal, description, inference, and self-regulation. Previous findings have found that while students are taught by inquiry-based learning compared with traditional educational strategies, the reflective writing skills of students are significantly higher. A preferable learning approach to the act of teaching that is marked by compulsory teaching is to provide an open means of student learning class where students exchange positive experiences in an inquiry process that is focused on curiosity.

Students can develop critical thinking skills by incorporating inquiry-based learning in writing classes, and learn how to create and arrange proposals to find alternate solutions and produce sound written articles through analysis discussion. Students who use inquiry-based learning methods in their language learning are also stronger attainders and they play an active part in selecting the writing topics and creating the findings of their own study. Inquirybased learning in EFL classes has an effect on helping students strengthen the target language and gain other skills required to grasp this ever-changing environment. When students participate in real life situations, they can improve effective reflective skills, adapt and respond better to change, and they are also prepared to the development of critical thinking skills (Escalante, 2013; Ismail, 2006; Lessner \& Craig, 2010).

Studies conducted by ( Ash and Kluger-Bell, 2012);( Byker, Harden, Heafner, and Holzberg, 2017);( Ahmad et. al ., 2014) illustrated that students favored and performed much better with the level of confirmation of inquiry compared to directed, coordinated and transparent inquiry because teachers have all required conditions and give the student the freedom to study freely at the level of confirmation.

The students discover writing subjects in inquiry-based writing instruction; discuss knowledge on their themes; explain their observations, and elaborate their reasoning by translating their interpretation into their actual life circumstances. Therefore, as students manipulate these assignments in this independent process, their logical reasoning abilities 
increase and this process improves the capacity of students to interpret, synthesize, and compare multiple thoughts. Using inquiry-based learning in the writing class increases the efficiency of the students' reflective essay writing because the approach helps them to explore their own writing subjects, create ideas, collect and review facts, compose proof drafts, consult with peers and experts in the field, and produce reflective essays.

\section{Concerning the reducing of writing apprehension:}

There were statistically significant differences between the mean scores of the experimental group in their responses on the post- administration of writing apprehension scale compared to the pre- administration, favoring the post one. The students' progress in the post administration of the writing apprehension scale could be attributed to the use of the inquiry based learning program. This program increased the students' motivation to be not fear of writing and reducing their writing apprehension through using free inquiry activities. The core elements of inquiry-based learning. Inquiry is a multifaceted practice that encourages learners to ask or produce meaningful questions that lead to the appropriate answers. In education, learners are shown how information is produced and communicated and how the knowledge and skills required to become life-long learners can be learned.

The researcher demonstrated the key factors shaping the fear of writing (writing apprehension). From the responses of the students, four types of variables emerged: personal factors, psychological factors, social factors and academic factors. The first factor consisted of three sub-themes: fear, physical issues, and depression, which were personal causes. The psychological aspect includes their subjective reactions to the objects on the scale. The social influences were found to be related to the relationship between the students and their teacher, or to the relationship between the students and community. It has two isolated and humiliating sub-themes. Academic variables that contributed to poor academic success were the last factor found in this analysis.

\section{Conclusions:}

Based on the results of the research, the following could be concluded:

1. Results of the study proved the effectiveness of inquiry based learning program in developing EFL postgraduate students 'reflective writing skills and decreasing writing apprehension.

2. Reflective writing is seen as a vital aspect to move students-writers to internalize the understandings that are arrived at through dialogues as well as to encourage them to apply their new ways of thinking to their lives. Reflective essays can happen this. In this perspective, it can be understood that students' writings are developed from their reflections. In this research, reflective writing is used as a vehicle for internalization.

3. Inquiry based learning program is used to facilitate the educational material, help to create a positive learning experience, make students more excited about the educational material and help them carry out their writing tasks with more enthusiasm and responsibility.

4. There is a positive attitudes towards using the inquiry based learning program as it motivate students and make them interested in learning.

5. The program was effective in decreasing the level of writing apprehension among the EFL students. 


\section{Recommendations:}

6. The major variations found in favor of the post-test of the reflective writing skills of the EFL and the pre-administration of the written apprehension can also be due to the application of an inquiry-based learning curriculum. Thus, in developing EFL reflective writing skills and reducing writing apprehension among the research participants, the program proved to be successful.

Based on the results of the present research, the following recommendations should be taken into consideration:

1- The EFL reflective writing skills should be given due attention.

2- Students should be given the freedom to choose the topics they want to write about or they are interested in or that are more relevant to their habits.

3- Students should write about the link between their experiences/practice and their reading

4- - Since it entails writing about thoughts (anxieties and faults, as well as successes), reflective writing can be more complex than other types of writing.

5- It will encourage students to begin writing by explaining a case.

6- For their own learning, students should set concrete and practical expectations.

7- Students should take the opportunity to communicate with mentors, to interact together with others and to exchange experiences of learning with peers;

8- Instructor should assist students in formulating learning objectives and determining the most effective ways to accomplish them;

9- Instructor can help students develop learning patterns, master learning techniques, and develop metacognitive abilities to direct their learning;

10-In order for students to be intellectually interested, an instructor should create a relaxing and inspiring learning background.

11- Teacher should provide a forum for learners to organize their research in a structured way, particularly those struggling learners; and

12-A positive, tolerant and mutually positive learning environment should be created by the instructor to allow students to participate actively in learning without fear of being judged.

\section{Suggestions for further researches}

The following suggestions for further research have been formulated based on the conclusions of this study.

1- Examining the efficacy of the inquiry-based learning curriculum for prospective instructor students in the English language.

2- Clarifying the effect of inquiry-based learning on other language abilities, such as reading, or listening.

3-Exploring the efficacy of other techniques or methods in the development of reflective writing and reducing apprehension of writing. 
4- Investigating several methods to improve the other sub- skills of reflective writing

\section{References}

Abu- Shawish, J., \& Atea, M. (2010). An Investigation of Palestinian EFL Majors' Writing Apprehension: Causes and Remedies. Proceedings of the First National Conference on: Improving TEFL Methods \& Practices at Palestinian Universities. Retrieved from http://www.eric.ed.gov/contentdelivery/servlet/ERI CServlet? accno=ED512894 http://search.proquest.com/docview/822507363? accountid=30641

Aditomo, A., Goodyear,P. Bliuc, A.M., \& Ellis, R.A., (2013). Inquiry-based learning in higher education: principal forms, educational objectives, and disciplinary variations, Studies in Higher Education, 38:9, 1239-1258, DOI: 10.1080/03075079.2011.616584.

Ahmad, N., Khan, F. N., Munir, N., et al. (2013). Factors affecting the learning of English at secondary school level in Khyber Pakhtunkhwa, Pakistan. International Journal of English Language and Literature Studies, 2 (2), 95-101.

Ahmad, J., Sitti, H., Rais- Abdul, R., Hamdan, D. Mohammad N., Gaffar, Sanitah, M. \& Yusof, A. (2014). Levels of inquiry based learning skills in English language among high school students: a study in Maksaar Indonesia. Journal of Language and literature 2014, 5(2), 62-66.

Ajit, I., Ramesh, M \& Arun, G. (2016).Higher Order Thinking Skills through Online Discount Coupons. Journal of Recent Research and Applied Studies. Vol. 3, Issue 5

Al-Ahmad, S. (2003). The impact of collaborative learning on L1 and L2 college students' apprehension about and attitudes toward writing. Unpublished doctoral dissertation, Indiana University of Pennsylvania, USA.

Alberta Learning. (2004). Focus on Inquiry: A Teacher's Guide to Implementing InquiryBased Learning. ERIC number: ED491498. http://files.eric.ed.gov/fulltext/ED491498.pdf .

Albert education. (2005). A teacher's Guide to implementing inquiry based learning.

Al-Sawalha, A, \& Chow, T. (2012). The Effects of Proficiency on the Writing Process of Jordanian EFL University Students. Academic Research International, 3(2), 379- 388.

Al-Shboul ,Y (2015)The Causes of Writing Apprehension through Students' Perspective. Journal of Language Teaching and Research. Vol 6, No 3 (2015).

Ash,D and Kluger-Bell, B (2012). Identifying Inquiry in the K-5 Classroom. Retrieved from http://www.nsf.gov/pubs/2000/nsf9 9148/ ch_10. htm.

Asselin, M., Branch, J. \& Oberg, D. (2003.) Achieving information literacy standards for school library programs in Canada. O.N: Canadian School Library Association. (atas talian) http://ednet.edc.gov.ab.calk-12/curriculum/by 
Atay, D., \& Kurt, G. (2006). Prospective teachers and L2 writing anxiety. Asian EFL Journal, 8(4), 100-118.

Bernstein, A. (1978). "Errors and Expectations: A guide for the Teacher of Basic Writing by Mina P. Shaughnessy", The School Review, 86 (2), (1978): 292-294

Boice, R., (1993). "Writing Blocks and Tacit Knowledge". The Journal of Higher Education, 63(1), (1993):19-54.

Borich, G. (2004). Effective Teaching Methods. Fifth Edition, New Jersey, 2004.

Broek, G. (2012), "Innovative Research-Based Approaches to Learning and Teaching", OECD Education Working Papers, No. 79, OECD Publishing. http://dx.doi.org/10.1787/5k97f6x1kn0w-en.

Brown, H. (2000). Principles of Language Learning and teaching (4th edition).New York: Longman.

Byker, E., Coffey, H., Harden, S., Good, A., Heafner, T., Brown, K., \& Holzberg, D. (2017). Hoping to Teach Someday? Inquire Within: Examining Inquiry-Based Learning with FirstSemester Undergrads. Journal of Inquiry and Action in Education, 8(2). Retrieved from https://digitalcommons.buffalostate.edu/jiae/vol8/iss2/4

Caputo,L.(2014).Using inquiry based learning to teach additional languages in a high school context. https://www.researchgate.net/publication/305307419.

Cheng, Y. (2002). A measure of second language writing anxiety: Scale development and preliminary validation. Journal of Second Language Writing, 13, 313-335.

Chuo, T. (2004). The effect of the web quest writing instruction on EFL learners' writing performance, writing apprehension, and perception. Unpublished doctoral dissertation, La Sierra University, Taiwan.

Clarke, J. (1990). Patterns of thinking: Integrating learning skills in content teaching. Needham Heights MA: Allyn and Bacon.

Clark, D. (2005). Explorations into writing anxiety: Helping students overcome their fears and focus on learning. Paper presented at the ISSOTL Conference, Canada.

Claypool, S. (1980). Teacher writing apprehension: Does it affect writing assignments across curriculum? (ERIC Document Reproduction Service No: ED 216 387).

Condon, W., \& Kelly-Riley, D. (2004). Assessing and teaching what we value: The relationship between college-level writing and critical thinking abilities. Assessing Writing, 9(1), 56-75. https://dx.doi.org/10.1016/j.asw.2004.01.003 
Connell, T., \& Dyment, J. (2006). Reflection on using journals in higher education: a focus group discussion with faculty, Assessment\& Evaluation in Higher Education, 31:6, 671-691, DOI: $10.1080 / 02602930600760884$.

Crème, P. (2005).Should Student. Learning journals should be assessed. Assessment Evaluation in Higher Education, 30(3), 287-296

Daly, J., \& Miller, M. (1975). Apprehension of writing as a predictor of message intensity. Journal of Psychology, 89, 75-177.

Daly, J. \& Shamo, W. (1978). Academic decisions as a function of writing apprehension. Research in the Teaching of English, 2 (2), 119126.

Dally, J., Vangelist, A. \&Witte. (1988). Writing apprehension in the classroom context. The social construction of written communication, 7(3), 147-171

Daud, N., Daud, N., \& Kassim, N. (2005). Second language writing anxiety: Cause or effect. Malaysian Journal of ELT, 1(1), 1-19.

Dewey, J. (1937). How we think: A restatement of the relation of refl ective thinking to the educative process (Revised edition). Boston, MA: D. C. Heath.

Dickson, K. (2001). "Free Writing Prompts and Feedback". The Internet TESL Journal, 7(8), (2001).

Escalante, P. (2013). Inquiry-Based Learning in an English as a Foreign Language Class: A Proposal. Journal of Modern Language, 19: 479-485.

Exline, J. (2004). Concept to classroom. Inquiry-based learning (atas talian) http://www.thirteen.org/edonline/concept2class/inquiry/credit "Focus on inquiry". Alberta learning. 2004. Alberta, Canada. (atas talian) http://ednet.edc.gov/ab.calk12/curriculum/bysubject/focusoninquiry.pdf

Fielding, M. (2012). Beyond student voice: Patterns of partnership and the demands of deep democracy. Revista de Educación, 359, 45-65.

Friesen, S. (2010). Uncomfortable bedfellows: Discipline-based inquiry and standardized examinations. Teacher Librarian, 37(6).

Gere, A., Schuessler, B., \& Abbott, R. (1984). Measuring teachers' attitudes toward writing instruction. In R. Beach \& L. Bridwell (Eds.), New Directions in Composition Research (348361). New York: Guilford.

Grabe, W., \& Kaplan, R. (1995). Theory and Practice of Writing. The USA: Longman.

Hackbert, P. (2002). Reflective Practice: Writing and Professional Development. Third Edition. London: Paul Chapman Publishers. 
Haider, G. (2012). An insight into difficulties faced student writers: Implications for teaching of writing. Journal of Educational and Social Research, 2 (3), 17-27.

Hanna, K. (2010). Student perceptions of teacher comments: relationships between specific aspects of teacher comments and writing apprehension. Unpublished doctoral dissertation, University of North Dakota.

Hassan, B. (2001). The relationship of writing apprehension and self-esteem to the writing quality and quantity of EFL university students. Mansoura Faculty of Education Journal, 39, $1-36$.

Helwa, L.(2013). Reflective Practice: Writing and Professional Development. Sage, London

Helyer, R (2015). "Learning through reflection: the critical role of reflection in work-based learning (WBL)". Journal of Work-Applied Management. 7: 15-27. doi:10.1108/JWAM-102015-003.

Hettich, R. (1994). Writing apprehension: A critique (Doctoral dissertation). Pro Quest Dissertations and Theses. Retrieved from http://210.48.222.80/proxy.pac/docview/304130502? accountid $=44024$

Holladay, S. (1981). Writing anxiety: What research tells us. Retrieved from http://eric.ed.gov/?id=ED216393

Huwari, I. \& Hashima, N. (2011). Writing apprehension in English among Jordanian postgraduate students in UUM. Academic Research International Journal, 1(2), 190-198.

Huwari, I \&Al-Shboul, Y.(2015). The causes of writing apprehension through students'perspective. Journal of language teaching and research, 6(3), 535-544.

Hyland, K. (2003). Second language writing. Ernst Klett Sprachen.

Ismaile, N. (2006). Inquiry based learning: New approach to classroom learning. English Language Journal,2(1), 13-24.

Johnson, L. \& Adams, S., (2011). Challenge Based Learning: The Report from the Implementation Project. Austin, Texas: The New Media Consortium..

Jonassen, D. (2000). Computers as mind tools for schools. Engaging critical thinking (2nd Ed). Upper Saddle River, New Jersey: Prentice Hall.

Kellogg, R. T., \& Raulerson, B. A. (2007). Improving the writing skills of college students. Psychonomic bulletin \& review, 14 (2), 237-242.

Killen, R. (2003). Effective teaching strategies lessons. From research, a Science Press. 
Kluger-Bell, B. (2012). Identifying Inquiry in the K-5 Classroom. Retrieved from 16 http://www.nsf.gov/pubs/2000/nsf9 9148/ ch_10. htm. Brookes, A and Grundy, P. (2000).

Kurk, G., \& Atay, D. (2007). Students' Writing Apprehension. Journal of Theory and Practice in Education, 3(1), 12-23.

Lessner, S., \& Craig, C. (2010). Invention as inquiry-based learning in first year writing. Writing Spaces: Readings on Writing, 1(1), 126-45.

Li, M. (2012). Use of wikis in second/foreign language classes: A literature review. CALLEL, 13(1), 17-35.

Linh, G. (2010). An exploration into foreign language writing anxiety from Taiwanese university students' perspectives. Paper presented at the NCUE Fourth Annual Conference on Language, Teaching, Literature, Linguistics, Translations and Interpretation, Taiwan. doi: 10.1111/0026-7902.00016

Mc Gregor, J. (2003). Collaboration and leadership. Dlm Stripling, B. \& Hughes, S. (Eds). Curriculum connections through library. Westport CT: Libraries Unlimited.

Moon, J. (2004). A Handbook of Reflective and Experiential Learning. Routledge Falmer, London

Moon, J. (2007). Reflective Learning Workshop Handout. Retrieved from www.worc.ac.uk/edu/documents/Jenny_Moon_RefLearnlong07.doc.

Nik, Y., Hamzah, A., \& Rafidee, H. (2010). A comparative study on the factors affecting the writing performance among Bachelor students. International Journal of Educational Research and Technology, 1 (1), 54-59.

Nik, Y., Sani, B. B., Kamaruzaman, M., Hasbollah, H, et al. (2010). The writing performance of undergraduates in the University of Technology, Mara, Terengganu, Malaysia. Journal of Languages and Culture, $1(1), 8-14$.

Olanezhad, M. (2015). A comparative study of writing anxiety among Iranian university students majoring English translation, teaching and literature. English Language Teaching, 8(3), 59-70. https://dx.doi.org/10.5539/elt.v8n3p59

Palmquist, M., \& Young, R. (1992). The notion of giftedness and student expectations about writing. Written Communication, 9, 137-169.

Papacek, M.(2010). Inquiry based science education: A way for the biology education of generations Y, Z, and alpha? Scientia in educatione 1(1), 2010 p. 33-49. [online] 2010b [cit. 2010-10-05] Dostupné na WWW: http://www.pf.jcu.cz/stru/katedry/bi/DiBi2010.pdf. ISBN 978-80-7394-210-6. 
Pappalardo, P.(2010) 'Teacher behavior and attitude and student writing apprehension', $\mathrm{PhD}$ thesis, School of Graduate Studies and Research, Indiana University of Pennsylvani.

Petr, J. (2010). Inquiry- based instruction concept. Essence, importance, and contribution.

https://www.researchgate.net/publication/278406129_h, 2010. 165 p. p. 136-144.

Pineteh, E. A. (2013). The academic writing challenges of undergraduate students: A South African case study. International Journal of Higher Education, 3 (1), 12.

Pool, (2001). Exploring the impact of a high-stakes direct writing assessment in two high school classrooms Research in the Teaching of English 35(3):344-390

Prince, M. \& Felder, R. (2006). Inductive teaching and learning methods: Definitions, comparisons, and research bases. Journal of Engineering Education 95, 123-138.

Quintero, L. (2008). Blogging: A way to foster EFL writing. Colombian Applied Linguistics Journal, 10 (1), 7-49.

Rankin-Brown, M. (2006). Addressing Writing Apprehension in Adult English Language Learners. In Proceedings of the CATESOL State Conference, 2006, Pacific Union College.

Rathakrishnan, M. \& Umar, I. (2010). Wiki as a collaborative tool in education: A case study. AACE Asia Pacific Global .Learn Conference Proceedings, 17 (1), 348-35.

Reeves, L. (1997). Minimizing writing apprehension in the learner-centered classroom. The English Journal, 86(6), 38-45. http://dx.doi.org/10.2307/820367

Reio, S. (2010). Investigation of the relations between domain- specific beliefs about writing, writing self-efficacy, writing apprehension and writing performance in undergraduates. Florida International University.

Rico, L. J. A. (2014). Identifying factors causing difficulties to productive skills among foreign languages learners. Opening Writing Doors Journal, 11 (1), 65-86.

Roestiyah, N. (2001). Strategi Belajar Mengajar. Jakarta: Rineka Cipta.

Salem, M. (2007). The effect of journal writing on written performance, writing apprehension, and attitudes of Egyptian English majors (doctoral dissertation). Retrieved April 7, 2015 from https://etda.libraries.psu.edu/paper/7894/3200.

Sanjaya, W. (2010). Strategi Pembelajaran Berorientasi Standar Proses Pendidikan. Jakarta: Prenada.

Schneider, H. \& Daniel K. (2012). Inquiry-based learning. Retrieved from http://edutechwiki.unige.ch/en/Inquiry-based_learning 
Stapa, S. \& Abul- Majid, A. (2009). "The Use of First Language in Developing Ideas in Second Language Write”, European Journal of Social Sciences, 7 (4), (2009).

Stevens, P. (2006). Iquiry learning and second language teaching. Cambridge University. Press 2006

Stover, K. (1988). Riposte: in defense of free writing English Journal, 77(2), 61-62 Retrieved from http://eric.ed.gov/EricwebPortal/search/detailmini-jsp?-nfpb=true\&EricExtsearch-search value-D-EJ373355\&Eric Exit search-search type-0=no\&accno=EJ373355

Suhartono, et.al. (2014). The Influence of Learning Method of Student Teams-Achievement Divisions (STAD), Inquiry Based Learning (IBL), and Expository (Conventional), and Reading Interests toward Writing Competence. Asian Journal of Science nd Technology, Vol. 5 Issue 9, p. 600-605.

Thirteen, L (2012). Step-by-step facilitation plan creation. Retrieved from http://www.thirteen.org/edonline/co ncept2class/inquiry/implement_sub2. htm

Trianto, G. (2011). Mendesain Model Pembelajaran Inovatif-Progresif: Konsep, Landasan, dan Implementasinya pada Kurikulum tingkat Satuan Pendidikan (KTSP). Jakarta: Kencana Prenada Media Group.

Umar, I. \& Rathakrishnan, M. (2012). The effects of online teachers' social role and learning style on students' essay writing performance and critical thinking in a Wiki environment. Procedia - Social and Behavioral Sciences 46 (2012) 5730 - 5735.

Veit, R. (1980). Reducing writing apprehension in English classes. Paper presented at the Annual Meeting of the National Council of Teachers of English. Cincinnati, United States.

Wachholz, P. \& Etheridge, C. (1996). Writing self- efficacy beliefs of high and low apprehensive writers. Journal of Development Education 19. 16-24.

Williams, K., Woolliams, M., \& Spiro, J. (2012). Reflective Writing. Basingstoke: Palgrave Macmillian 
برنامج قائم علي التعلم بالاستقصاء لتنمية مهارات الكتابة التأملية و خفض درجة التخوف الكتابي لاي طلاب الاراسات العليا تخصص مناهج وطرق تلاريس اللغة الانجليزية.

\author{
مني صلاح عبالله عثمان \\ مدرس بقسم العلوم التربوية و النفسية"تخصص مناهج و طرق تدريس اللغة \\ الانجليزية. كلية التربية النوعية - جامعة الزقازيق - مصر
}

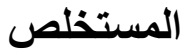

يهدف البحث الحالي إلى دراسة تأثير برنامج قائم علي التعلم بالاستقصاء في تتمية مهار ات الكتابة التأملية، وخفض درجة التخوف الكتابي لدى طلاب الدر اسات العليا (برنامج المناهج وطرق باتئ تدريس اللغة الانجليزية) بكلية التربية النوعية جامعة الزقازيق( دراسة شبه تجريبية)، حيث قام الباحث بتقسيم عينة

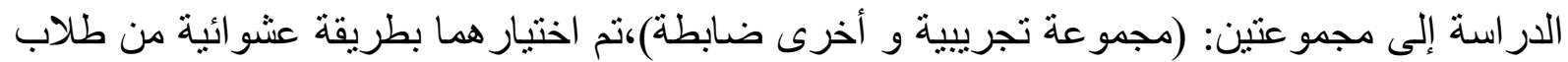

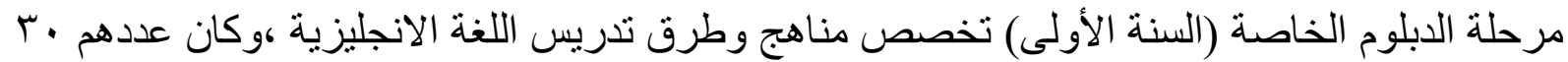

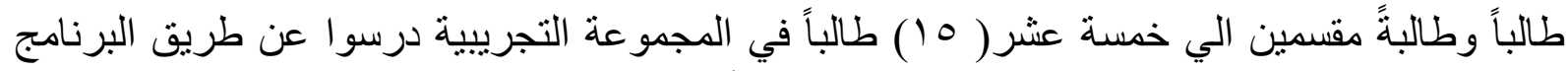
القائم علي التعلم بالاستقاء وخمسة عشر(0 10) طالباً في المجموعة الضابطة تم تدريسهم بالطريقة التقليدية، وتم اختبار تلك المجمو عتين قبل وبعد تطبيق البرنامج. .

تكونت أدو ات الدراسة من أختبار لقياس مهار ات الكتابة التأملية و مقياس ديلي- ميلر لأختبار نسبه

التخوف الكتابي. و أسفرت الدر اسة عن النتائج التالية:

ا -وجود فروق دات دلالة إحصائية بين المجمو عتين التجريبية و الضابطة في التطبيق البعدي لمهار ات

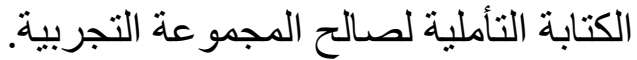

ץ- وجود فروق دات دلالة إحصائية بين المجموعتين التجريبية و الضابطة في التطبيق البعدي لمقياس التخوف الكتابي لصالح المجمو عة التجربية.

זـفعالية البرنامج القائم علي التعلم بالاستقصاء في تنمية مهار ات الكتابة التأملية و خفض درجة التخوف الكتابي لدي طلاب المجمو عة التجريبية.

الكلمات المفتاحية: التعلم بالاستقصاء، الكتابة التأملية،التخوف الكتابي،طلاب الاراسات العليا،كلية التربية النوعية، 